Kafr El-sheikh University

Faculty of Commerce

Accounting Department

\title{
The Effect of Internal Corporate Governance \\ Mechanisms on the Disclosure of Internal Control \\ Material Weaknesses \\ With a Field Study
}

\author{
Prepared by \\ Dr. Aly Mogahed Ahmed \\ Associate Professor of Accounting \& \\ Chairman of Accounting Department \\ Faculty of Commerce Kafr El-Sheikh University
Dr. Ayman Mohamed Sabry Nokhal
Lecture at Accounting Department
Faculty of Commerce
Kafr El-Sheikh University

\author{
Hadeer Metwally Rashad Metwally \\ Demonstrator at Accounting Department, \\ Faculty of Commerce \\ Kafrelsheikh University
}


The Effect of Internal Corporate Governance Mechanisms on the Disclosure of Internal Control Material Weaknesses: With a Field Study

\section{Abstract:}

This research aims to examine the effect of internal corporate governance mechanisms with particular reference to (board of director and audit committee (AC) characteristics) on the disclosure of internal control material weaknesses (ICMWs) in the Egyptian environment. Using a sample composed of 240 usable questionnaires were collected from a number of executive and financial officers, internal auditors, audit committee members in the Egyptian listed companies, and external auditors working in different-size audit firms. The statistical techniques used to test the hypotheses of this research are binary logistic regression and Kruskal-Wallis test.

The findings revealed that board of directors' size, board of directors' independence, board of directors' diligence, audit committee size, and audit committee financial expertise have significant positive impact on the disclosure of ICMWs in the Egyptian environment. The results also found a significant negative effect of role duality on the disclosure of ICMWs in the Egyptian environment. However, no significant effect of audit committee independence on the disclosure of ICMWs has been found in the Egyptian environment. Overall, this research demonstrated that board of director and $\mathrm{AC}$ characteristics are crucial determinants of disclosure of ICMWs in the Egyptian setting

Keyword : Internal Control Material Weaknesses (ICMWs); Audit Committee.

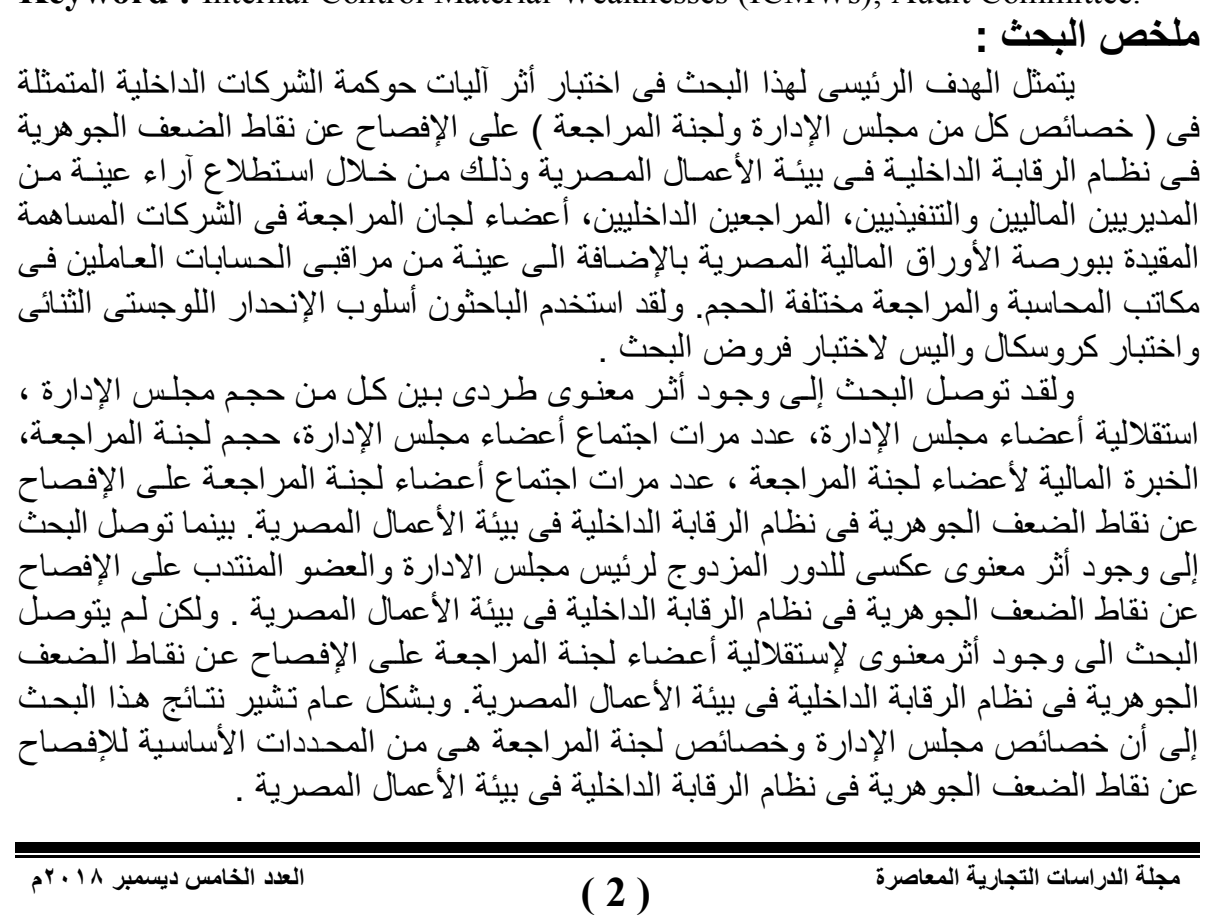




\section{The General Framework of Research. \\ 1.1 Introduction.}

Business organizations have witnessed a series of corporate collapses, an increasing of fraudulent practices, and accounting inconsistencies in highly successful firms such as Enron, Adelphia and WorldCom and large audit firms such as Arthur Anderson which contributed significantly to their downfall, causing loss of confidence of shareholders and other stakeholders in the financial markets in the United States and the rest of the world. In response to these scandals, regulators, professional organizations, and governments have passed a wide range of laws and corporate governance codes with the purpose of enhancing the credibility and reliability of financial reporting.

In order to enhance the accuracy and reliability of corporate financial reporting and to restore investor confidence in the financial markets, the U.S. Congress released the Sarbanes Oxley Act (SOX) in 2002 as a result of many corporate frauds. One crucial aspect of SOX is the internal control provisions. Section 302 of SOX requires both the chief executive officer (CEO) and chief financial officer (CFO) to evaluate and report on the internal control system's effectiveness in their firm's annual financial reports and disclose any material weakness exist in it. Further, Section 404 of SOX have two provisions: section 404 (a) of SOX requires the management to provide an assessment of the company's internal control system's effectiveness, and section 404 (b) of SOX requires the auditors to provide an opinion on both management's assessment and on the effectiveness of the company's internal control over financial reporting. Prior to SOX, companies registered in Securities and Exchange Commission (SEC) were required only to disclose Internal Control Material Weaknesses (ICMWs) if there was a change in auditor (Krishnan, 2005a; Doyle et al., 2007).

Auditing standard No.2201 described the internal control over financial reporting (ICFR) as "a process designed and implemented by the company's executive and financial officers, or persons performing similar functions, and affected by the company's board of directors, management, and other personnel, to provide reasonable assurance regarding the reliability of financial reporting and the preparation of financial statements for external purposes in accordance with generally accepted accounting principles (GAAP) and includes those policies and procedures that:

(1) Relate to the maintenance of records that, in reasonable detail, accurately and fairly reflect the transactions and dispositions of the company's assets;

مجلة الاراسات التجارية المعاصرة


(2) Provide reasonable assurance that transactions are recorded as necessary to permit preparation of financial statements in accordance with generally accepted accounting principles and that receipts and expenditures of the company are being made only in accordance with authorizations of management and directors of the company; and

(3) Provide reasonable assurance regarding prevention or timely detection of unauthorized acquisition, use, or disposition of the company's assets that could have a material effect on the financial statements" (PCAOB, 2015).

Auditing standard No.2201 also determined three levels of internal control deficiency based on the likelihood that a material misstatement of annual or interim financial statements might result as follows:

1. A Control Deficiency is "a deficiency or a combination of deficiencies in internal control over financial reporting, such that there is a reasonable possibility that a significant misstatement of the company's annual or interim financial statements will not be prevented or detected".

2. A Significant Deficiency is "a deficiency or a combination of deficiencies in internal control over financial reporting, that is less severe than a material weakness yet important enough to merit attention by those responsible for oversight of the company's financial reporting".

3. A Material Weakness is "a deficiency or a combination of deficiencies in internal control over financial reporting, such that there is a reasonable possibility that a material misstatement of the company's annual or interim financial statements will not be prevented or detected on a timely basis" (PCAOB, 2015).

The existence of material weaknesses in internal control system entails procedural and estimation errors as well as opportunistic earnings management, thereby deteriorating corporate transparency (Kim et al., 2017, p.7-8). The lack of transparency in financial reporting enables managers to opportunistically withhold bad news or unfavorable information (Jin and Myers, 2006; Kim et al., 2011a; Kim and Zhang, 2014). The disclosure of internal control material weaknesses induces a heightened degree of scrutiny and external monitoring by outside investors which in turn, motivate corporate insiders to be more forthcoming with respect to bad news disclosure (Kim et al., 2017, p.33).

Corporate Governance has gained prominence in the Egyptian context. Since the early 1990s, Egypt started implementing an 
economic reform program, the Egyptian government revitalized its capital market, by improving its reputation and building confidence among investors (Desoky \& Mousa, 2012). Consequently, various reforms of corporate governance have been formulated, developed and enacted. One of these reforms is the Egyptian Corporate Governance code that was issued in light of OECD guidelines in 2005 and was updated in 2011 and 2016.

According to the Egyptian' Corporate Governance Code, corporate governance is a set of foundations, principles and systems that govern the relationship between board of director on one hand and the company's owners and other stakeholders on the other hand in order to achieve the optimum protection and balance between interests of all those parties (ECCG, 2016, p.8).

Corporate governance practices enhance the accuracy of disclosed information and organize the relationship between the shareholders, board of directors and management (Ezat \& El-Masry, 2008, p.853). Further, the corporate governance structure itself encourages managers to adopt the best disclosure policy (Karamanou $\&$ Vafeas, 2005). Many prior studies investigated the determinants of disclosure of ICMWs in the developed countries and suggested that corporate governance mechanisms are major determinants of the disclosure and remediation of internal control material weaknesses. Very few research had been done in the developing countries. So, this research seeks to investigate the effect of internal corporate governance mechanisms on the disclosure of internal control material weaknesses in the Egyptian environment.

\subsection{Research Problem.}

Egypt witnessed a serious of institutional and corporate scandals as a result of weak internal control systems and poor corporate governance practices, such as the bank failures in 2000, which resulted from enormous amounts of bad loans, the Egyptian General Petroleum Corporation (EGPC) bribery scandal in 2007, the mismanagement of the public pension funds scandal (2002-2004). Also, the latest results from Transparency International (2015) which ranked Egypt 88th on the latest Corruption Perception Index (CPI) (El-Diftar, 2016 as cited in Sorour, 2014).

In order to enhance corporate governance practices, economic efficiency, and attract more local, regional and foreign investors in the Egyptian stock market. New information should be provided to investors and other stakeholders to rebuild their confidence in the published financial reporting. The disclosure of internal control material weaknesses (ICMWs) may be considered new and valuable 
information that can help investors and other stakeholders in assessing their investment alternatives and taking the optimal investment decisions. Further, it helps companies to establish an effective control environment to prevent fraud, misdirection of corporate resources, and opportunistic actions by managers which resulted in more reliable and transparent financial reporting and better corporate governance practices.

Prior studies investigated the relationship between corporate governance mechanisms and the disclosure and remediation of internal control material weaknesses provided conflicting results. For instance, Owusu \& Ganguli, (2010, p.403); Yazawa, (2015, p.103); Huang et al., (2017) found a positive relationship between board independence and disclosure of ICMWs. Ji et al.,(2015, p.10) found negative relationships between (board independence and board size) and disclosure of ICMWs. Krishnan, (2005, p.671) found negative relationships between internal corporate governance characteristics (Audit committee financial expertise and audit committee independence) and disclosure of internal control material weaknesses. But, Ji et al., (2015, p.10) and Stephens, $(2009,2011$, p.126) found a positive relationship between audit committee financial expertise and disclosure of ICMWs. However, those prior studies were conducted in different foreign environments. There is little evidence from developing countries such as Egypt about the determinants of disclosure of internal control material weaknesses. So, this research tries to investigate the effect of internal corporate governance mechanisms (board of director and AC characteristics) on the disclosure of internal control material weaknesses in the Egyptian context to fill the research gap and enrich internal control material weaknesses disclosure literature in the Egyptian environment. The research problem can be summarized in the following main research question:

" Do Internal Corporate Governance Mechanisms affect the disclosure of internal control Material weaknesses (ICMWs) in the Egyptian Environment?".

However, in order to answer this question, the following subquestions should be answered :

1. Does board of directors' size affect the disclosure of ICMWs in the Egyptian environment?

2. Does board of directors' independence affect the disclosure of ICMWs in the Egyptian environment?

3. Does role duality affect the disclosure of ICMWs in the Egyptian environment? 
4. Does board of directors' diligence affect the disclosure of ICMWs in the Egyptian environment?

5. Does audit committee size affect the disclosure of ICMWs in the Egyptian environment?

6. Does audit committee independence affect the disclosure of ICMWs in the Egyptian environment?

7. Does audit committee financial expertise affect the disclosure of ICMWs in the Egyptian environment?

8. Does audit committee diligence affect the disclosure of ICMWs in the Egyptian environment?

9. Are there significant differences among respondents' perceptions of the disclosure of internal control material weaknesses in the Egyptian environment.

\subsection{Research Objective.}

The main objective of this research is to investigate "the effect of internal corporate governance mechanisms on the disclosure of internal control material weaknesses in the Egyptian environment". objectives:

This objective can be achieved by the following sub-

1.Investigating the effect of board of directors' size on the disclosure of ICMWs in the Egyptian environment.

2.Investigating the effect of board of directors' independence on the disclosure of ICMWs in the Egyptian environment.

3.Investigating the effect of role duality on the disclosure of ICMWs in the Egyptian environment.

4.Investigating the effect of board of directors' diligence on the disclosure of ICMWs in the Egyptian environment.

5.Examining the effect of audit committee size on the disclosure of ICMWs in the Egyptian environment.

6.Examining the effect of audit committee independence on the disclosure of ICMWs in the Egyptian environment.

7.Examining the effect of audit committee financial expertise on the disclosure of ICMWs in the Egyptian environment.

8.Examining the effect of audit committee diligence on the disclosure of ICMWs in the Egyptian environment.

9.Analyzing the significant differences among respondents' perceptions of the disclosure of ICMWs in the Egyptian environment.

\subsection{Research Importance.}

The current research contributes to literature both in terms of theory and practice. 


\section{The Scientific Importance.}

- The corporate governance is a pivotal subject to which the researchers locally and internationally pay attention as well as worldwide professional organizations.

- It adds to the literature on internal control by examining the relationship between internal corporate governance mechanisms and the disclosure of internal control material weaknesses.

- The lack of accounting researches associated with the disclosure of internal control material weaknesses especially in the Egyptian context.

\section{The Practical Importance.}

- It is anticipated that the results of this research can enhance our understanding to the importance of maintaining an effective internal control environment to achieve a sound financial reporting system and to restore the investor confidence in Egyptian stock market.

- It is anticipated that the disclosure of internal control material weaknesses contributes to mitigating the agency costs arising from information asymmetry in the Egyptian environment.

- It is anticipated that the disclosure of internal control material weaknesses improves the credibility and transparency of financial reporting and enhance the compliance with corporate governance rules and principles in the Egyptian listed companies.

\subsection{Research Hypotheses.}

In the context of the research problem and its objectives, the following main hypothesis can be formulated as follows:

"There is no significant effect of internal corporate governance mechanisms on the disclosure of internal control material weaknesses in the Egyptian environment."

The main hypothesis can be divided into the following subhypotheses:

1.There is insignificant effect of board of directors' size on the disclosure of ICMWs in the Egyptian environment.

2.There is insignificant effect of board of directors' independence on the disclosure of ICMWs in the Egyptian environment.

3.There is insignificant effect of role duality on the disclosure of ICMWs in the Egyptian environment.

4.There is insignificant effect of board of directors' diligence on the disclosure of ICMWs in the Egyptian environment.

5. There is insignificant effect of audit committee size on the disclosure of ICMWs in the Egyptian environment.

6.There is insignificant effect of audit committee independence on the disclosure of ICMWs in the Egyptian environment.

مجلة الاراسات التجارية المعاصرة


7.There is insignificant effect of audit committee financial expertise on the disclosure of ICMWs in the Egyptian environment.

8.There is insignificant effect of audit committee diligence on the disclosure of ICMWs in the Egyptian environment.

9.There are insignificant differences among respondents' perceptions of the disclosure of internal control material weaknesses in the Egyptian environment.

\subsection{Research Methodology.}

In the context of research objectives and research questions that researchers try to answer about the effect of internal corporate governance mechanisms on the disclosure of internal control material weaknesses. The current research relied on both deductive and inductive approaches.

\section{Deductive Approach.}

This approach is used to identify ideas and theories from reviewing the prior literature, after that, the hypotheses are developed based on those theories. Therefore, the research process under such approach moves from general to specific (Saunders et al., 2011).

\section{Inductive Approach.}

This approach is used to collect the data of research through designing a questionnaire and distributing it to the sample's categories which consist of a group of financial officers, executive officers, audit committee members, internal auditors, and external auditors working in different-size audit firms, then, data are analyzed through the use of descriptive and inferential statistical techniques in order to reach conclusions and findings about the effect of internal corporate governance mechanisms on the disclosure of internal control material weaknesses in the Egyptian environment. Therefore, inductive approach moves from particular to general (Saunders et al., 2011).

\subsection{Research Limitations.}

The following points represent the limitations of the current research:

1.The research did not expose to examining other corporate governance characteristics such as internal audit function characteristics, external audit quality characteristics, ownership structure, and market mechanisms.

2.The research did not expose to investigating other determinants of disclosure of ICMWs (such as firm characteristics).

3.The research did not expose to developing a proposed framework of disclosure of ICMWs in the Egyptian environment.

\subsection{Organization of Research.}

In the context of the research problem and objectives, this research was divided into five sections:

مجلة الاراسات التجارية المعاصرة:


1. The General Framework of Research.

2. Literature Review.

3.The Conceptual Framework of the Relationship between Internal Corporate Governance Mechanisms and the Disclosure of Internal Control Material Weaknesses.

4. The Field Study.

5. Results, Conclusion and Recommendations.

\section{Literature Review.}

The issue of corporate governance and disclosure of internal control material weaknesses (ICMWs) has received a great attention from many researchers as a result of corporate collapses and highprofile accounting irregularities. Therefore, the prior studies related to the research object can be overviewed as follows:

2.1 Studies that Combine between Corporate Governance Mechanisms and the Disclosure of Internal Control Material Weaknesses.

\subsubsection{Zhang et al., (2007):}

They investigated the association between audit committee quality, auditor independence and the disclosure of internal control material weaknesses after the enactment of the Sarbanes-Oxley Act. Based on a sample comprises of 208 firms with internal control material weaknesses and, based on industry, size, and performance, match these firms to a sample comprises of 208 control firms without internal control material weaknesses. The results revealed that there was an association between audit committee quality and auditor independence and the disclosure of internal control material weaknesses. They also found that there was a negative association between audit committee financial expertise and the disclosure of internal control material weaknesses. The results also found positive relationships between auditor independence and auditor changes and the disclosure of internal control material weaknesses.

\subsubsection{Hoitash et al.,(2009):}

This research investigated the relationship between corporate governance mechanisms and disclosures of internal control material weaknesses (MW). Based on a sample comprises of 5,480 firm-year observations (3,911 accelerated and 1,569 non-accelerated filers). The results revealed that there were negative relationships between audit committee size, audit committee accounting and supervisory expertise, and board strength and the likelihood of disclosure of internal control material weaknesses. Further, the nature of MWs varied with the type of experience. However, these relationships were not detectable using Section 302 reports. They also found that

مجلة الاراسات النجارية المعاصرة


disclosure of internal control material weaknesses was associated with designating a financial expert without accounting experience or designating multiple financial experts.

\subsubsection{Owusu-Ansah \& Ganguli, (2010):}

This research aims to explore and investigate the relationship between internal corporate governance mechanisms, with particular reference to board of director characteristics and voluntary reporting on their internal control systems in annual reports prior to the enactment of the Sarbanes-Oxley Act. Based on a sample comprises of 419 of non-financial companies. The findings revealed that frequent audit committee meetings, board independence, and audit committee independence were significantly associated with management voluntary reporting on internal control systems. They also found that board size, multiple directorships, and insider stockholdings were significantly associated with voluntary reporting on the internal control systems. However, institutional stockholdings, auditor-type, and role duality are not significantly associated with voluntary reporting on internal control systems.

\subsubsection{Leng \& Yiran, (2011):}

They examined the relationship between corporate governance characteristics and the disclosure of internal control material weaknesses. Based on a sample comprises of 1309 Chinese listed nonfinancial companies in 2010. The results revealed that there were positive relationships between two part-time posts of chairman and general manager, directors' remuneration, directors' education level and supervisors' education level and disclosure of internal control material weaknesses. They also found that a significant negative relationship between the proportion of state ownership and the disclosure of internal control material weaknesses. However, insignificant relationships between board size, the degree of ownership concentration, the size of the board of supervisors, and the proportion of independent directors and disclosure of internal control material weaknesses were found.

\subsubsection{Goh \& Dan, (2013):}

This research examined whether the internal control provisions under the Sarbanes-Oxley Act (SOX) had a disciplining impact on the corporate governance structures of firms. Based on a sample comprises of 184 firms that report at least one MWs from August 2003 to December 2004, each of the $184 \mathrm{MW}$ firms is matched to a firm that does not report any ICMWs during the same period. The results revealed that MW firms had a greater turnover of outside directors and audit committee members than a matched-pair sample of 
control firms. They also found that MW firms had weaker corporate governance structures than the control firms prior to the MW detection, they also found that the MW firms showed significantly greater improvements in their corporate governance structures than the control firms. The findings also demonstrated that the market reacted positively to the improvement in board independence and audit committee size.

\subsubsection{Ji et al., (2015):}

This research examined the determinants and economic consequences of disclosure of internal control material weaknesses (ICMWs) by Chinese listed firms under the voluntary disclosure regime over 2010-2011. Based on a sample consists of 1,141 observations (529 observations in 2010 and 612 observations in 2011). The results revealed that the likelihood of disclosure of ICMWs was not only associated with firm characteristics such as business complexity, age, and profitability, but was also strongly related to corporate governance characteristics and ownership structure in Chinese listed firms, e.g. the concentration of the top 3 shareholders' ownership, independence of the supervisory board, political connections and tradability of shares. They also revealed that there was a significant negative relationship between severity of the ICMWs disclosed and earnings response coefficients (ERCs). However, audit assurance of ICRs had a significant moderating impact on the relationship between ICMWs and ERCs.

\subsubsection{Khlif \& Samaha, (2016):}

This research tested and assessed the relationship between audit committee activity, external auditor's size and internal control quality (ICQ) in the Egyptian context. It also investigated how external auditor's size moderated the association between audit committee activity and ICQ. To obtain relevant information about ICQ in Egypt, the authors developed a survey based on an internal control checklist and distributed among external auditors, based on a sample comprises of 86 of the most actively traded companies listed on the Egyptian Stock Exchange over the period 2007-2010. The findings revealed that there was a significant positive relationship between audit committee activity and ICQ. Further, Big 4 auditors contribute significantly to the improvement of the ICQ in the Egyptian context. Finally, the relationship between audit committee activity and ICQ is more pronounced when an organization was audited by a Big 4 audit firm. They also demonstrated that Big 4 auditors play a governance role in a weak legal environment as exists in Egypt by strengthening the effectiveness of audit committee meetings. 
2.1.8 Fitzgerald et al., (2017):

This research investigated the relationships between audit partner tenure and audit partner changes and the incidence of reported internal control deficiencies (ICDs) and material weaknesses (ICMWs), the quality of internal control reports (following PCAOB audit quality indicators), for large U.S. not-for-profit (NFP) organizations. The results revealed that audit partner tenure is negatively associated with the incidence of reported ICDs and ICMWs, the quality of internal control reports, and the severity of reported ICDs. They also indicated that auditors are less likely to classify a reported deficiency as an $\mathrm{MW}$, rather than as a significant deficiency (SD), as audit partner tenure increases. However, they found no relationship between either audit partner tenure or changes and the likelihood of remediation of internal control deficiencies and weaknesses.

\subsubsection{Oussii \& Taktak, (2018):}

They examined the association between internal audit function (IAF) characteristics and internal control quality. Using data gathered from 59 chief audit executives from Tunisian listed companies. This research also used a regression model to investigate research hypotheses related to the association between IAF characteristics and internal control quality. The results revealed that internal control quality is significantly and positively associated with IAF competence, internal audit quality control assurance level, follow-up process and audit committee's involvement in reviewing the internal audit program and results. Those findings also provided significant implications for regulatory bodies who are concerned with the internal control quality, managers and audit committees who determine IAF investment, oversight IAF activities and assess internal auditors' performance.

\subsection{Evaluation of Literature Review:}

1.Corporate governance mechanisms are major determinants of disclosure and remediation of internal control material weaknesses.

2.Internal corporate governance mechanisms with particular reference to board and audit committee characteristics were significantly associated with the disclosure of internal control material weaknesses.

3.Prior studies that tested the relationship between corporate governance mechanisms and disclosure of ICMWs not emphasize enough on the characteristics of both internal audit function and external audit quality. 
4.Big 4 auditors significantly contribute to the improvement of the Internal Control Quality (ICQ) in the Egyptian environment.

5-Lack of prior studies about determinants of disclosure and remediation of internal control material weaknesses in the Egyptian environment.

\subsection{The Major Distinction Between the Current Research and Previous Studies:}

1. Most prior studies that tested the relationship between corporate governance mechanisms and disclosure of internal control material weaknesses were conducted in foreign environments but little one emphasizes on the Egyptian context, so this research is conducted to fill the research gap in the Egyptian environment.

2. Most Prior studies that examined the association between corporate governance mechanisms and disclosure of internal control material weaknesses based on actual internal control reports of sample of listed companies, but the current research demonstrated selfadministrated questionnaire to collect the data and examine the effect of internal corporate governance mechanisms on the disclosure of ICMWs because of lack of internal control reports in the Egyptian companies.

3. The current research developed a proposed index for the disclosure of ICMWs in the companies listed on the Egyptian Stock Exchange.

3. The Conceptual Framework for the Relationship between Internal Corporate Governance Mechanisms and the Disclosure of Internal Control Material Weaknesses.

The disclosure of internal control material weaknesses provides additional information that can promote the credibility and transparency of financial markets and thus restore investor confidence in the published financial reporting. Previous studies concerned about examining the determinants that may affect the disclosure of internal control material weaknesses. One of these determinants is corporate governance mechanisms. Corporate governance mechanisms can be defined as a set of tools seeking to protect the rights of shareholders and other stakeholders through the proper commitment to the general principles of corporate governance and monitoring the companies' actual performance (Samy Mohamed,2013, p.120).

\subsection{The Concept of Disclosure of Internal Control Material Weaknesses.}

The professional standards such as AS.2201 and SAS.60 and legislations such as US-SOX and J-SOX defined and classified the material weaknesses in the internal control over financial reporting. In light of those standards and legislations the disclosure of internal 
control material weaknesses can be defined as a description of loopholes identified in a company's internal control over financial reporting by management. This description provides information about the nature of material weaknesses, its actual and potential impact on the presentation of the company's financial statements issued during the existence of the weakness. Further, the management should disclose the remediation actions that have been taken to correct the reported weaknesses to ensure the credibility and transparency of financial reporting.

Previous studies provided different classifications to the material weaknesses in an internal control system. For instance, (Ge \& Mcvay, 2005) classified them into the following categories including, account-specific, training, revenue-recognition policies, segregation of duties, period-end/accounting policies, account reconciliation, subsidiary-specific, senior management, technology issues. They also suggested that account-specific is the most common type of weaknesses, that occur in current accounts such as the accounts receivable, accounts payable, and inventory accounts which are usually associated with lack of qualified staff.

Moody's Investors Service (2004, 2006, 2007) classified MWs in internal control system into two types, account-specific MWs related to specific accounts or transactions such as (insufficient internal controls for income tax accounting, insufficient internal controls for accounting for receivables including bad debts, and improper accounting for derivatives) and company-level MWs related to general problems within the company itself such as (inappropriate reconciliation of accounts and financial statement preparation, inadequate internal controls related to revenue recognition policies, and ineffectiveness of internal audit or audit committee). Moody's also demonstrated that account-specific control problems are auditable through substantive testing and are easily corrected through adjusting entries, Whereas, company-level control problems are likely to be more severe and tend to represent as serious a threat to the financial reporting quality.

Ji et al., (2015), (2016), and (2017) classified MWs in internal control into accounting related ICMWs such as (finance and investment, assets management, financial reporting, and budgeting) and non- accounting related ICMWs such as (organizational structure, human resource management, research and development, and social responsibility). They also suggested that firms not only need to reinforce the internal control systems in accounting-related areas but also enhance the internal control systems in non-accounting-

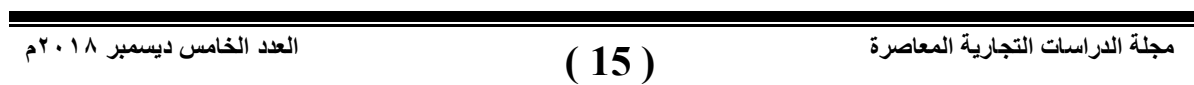


related areas, such as control environment, human resource management, and information systems etc. Boritz et al.,(2013), Masli et al., (2015, 2016) and Deng et al., (2016), Li et al.,(2017) classified MWs in internal control systems into Information Technology Material Weaknesses (ITMWs) such as (access, backup, master files, end- user computing) and non-ITMWs such as (Credit management, cost of sales, and fixed assets inspection). They also indicated that ITMWs generate greater uncertainty and risks within the internal control system than other types of ICMW. This is because IT controls are implemented to ensure appropriate access to, and security of, transaction data in the financial reporting process. Any material weaknesses in the system will impair the reliability of the firm's financial statements.

From the above classifications of material weaknesses in internal control over financial reporting, the researchers agree with prior studies that classified ICMWs into account-specific MWs and company-level MWs as it is considered the most important and thoroughness classification. In addition, the other classifications of material weaknesses in internal control system incorporated under this classification.

\subsection{Board of Director Characteristics.}

According to the Egyptian Code of Corporate Governance, (2016, p.11), the board of director is the authority that is responsible for setting goals and strategies and follow-up the performance of company's management in accordance with its status. The board can achieve its directing, monitoring and advisory functions through various characteristics. These characteristics include board size, board independence, role duality and board diligence. The current research examines the effect of those characteristics on the disclosure of internal control material weaknesses in the Egyptian Setting as follows:

\subsubsection{Board of Directors' Size.}

Board Size is a major determinant of the board's proper functioning. Boards of directors comprise mainly of two groups: inside directors, whose contractual ties allow them to make management decisions, and non-executive or external directors, who can be independent and represent majority shareholders (Fuente, 2017, p.739). It also serves as a fundamental intermediary between the parties in the financial reporting process (e.g. corporate management, audit committee, internal and external auditors) and has a key oversight function (Sultana et al., 2015). 
The Egyptian Code of Corporate Governance, (2016, p.16) also stipulated that board of director is formed from an appropriate number of members in a manner that support carrying out its functions and duties, including the formation of its committees. The majority of board members should be from non-executives, including at least two independent members with technical and analytical skills that will benefit the board and the company (Rule2-2-1).

Previous studies examined the relationship between board of directors' size and disclosure of internal control material weaknesses provided conflicting results. For instance, (Zhang et al., 2007, p.320; Owusu-Ansah \& Ganguli, 2010, p.403; Ji et al., 2015, p.10; Yazawa, 2015 , p.103) found a negative association between board of directors' size and disclosure of internal control material weaknesses. They suggested that a larger board can exert stronger monitoring and control over management and the company's internal control system. Thus, companies with the larger board are less likely to have ICMWs and thus, are less likely to disclose of ICMWs. However, (Leng and Yiran, 2011, p.286; Kwame \& Mensah, 2016, p.90) found no a significant relationship between board size and disclosure and remediation of internal control material weaknesses. Therefore, the non-directional null hypothesis can be formulated as follow:

H1: There is insignificant effect of board of directors' size on the Disclosure of ICMWs in the Egyptian environment.

\subsubsection{Board of Directors' Independence.}

According to the Egyptian Code of Corporate Governance, (2016, p.12) an independent board member is a non-executive board member who is not a shareholder in the company and he is appointed as a member of experience whose relationship with the company is limited to being a member of its board. Kwame \& Mensah, (2017, p.9) also showed that independent directors are members of companies' boards who are not employed by the firm. They act as a control mechanism as they perform an independent monitoring function.

Board independence had been considered as one of the key drivers of its ability to safeguard investor's and other stakeholder's interests (Fama and Jensen,1983). In the context of the agency theory, boards that had more independent directors are more likely to be effective monitors. As a consequence of their independence from the firm's management, non-executive and independent members can confront any self-interested actions or opportunistic behaviors by managers, and hence, agency costs are reduced (Fama,1980; Fama and Jensen, 1983). In contrary to the agency theory, advocates of the stewardship theory suggested that the performance can be improved if

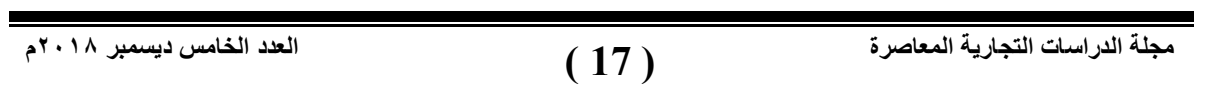


monitoring responsibility is centralized in the hands of inside directors because they are familiar with day-to-day operations (Donaldson and Davis, 1991).

The researchers agree with theoretical arguments of agency theory which suggests that the proportion of independent directors on the board is considered a crucial driver of effectively controlling and monitoring of management actions and helps to protect investors and other stakeholders' interests from any opportunistic behaviors or selfinterested actions by managers.

Previous studies examined the relationship between board independence and disclosure of internal control material weaknesses provided mixed results. For instance, (Owusu-Ansah \& Ganguli, 2010, p.403; Yazawa, 2015, p.103; Huang et al., 2017) found a positive relationship between board independence and disclosure of internal control material weaknesses. They suggested that the greater the number of outside directors in the company, the less likely it is that the company will furnish incorrect financial statements, where outside directors effectively monitor management's assessment and reporting on the internal control system. (Goh, 2009; Mitra et al., 2012, p.861) also found a positive association between board independence and timely remediation of internal control material weaknesses. They indicated that a more independent board is less susceptible to the undue influence of management and more able to exert pressure on management to remediate material weaknesses. Hence, a more independent board better protects shareholders' interests by improving the quality of internal control systems.

Kwame \& Mensah, (2016, p.90) also showed a significant relation between board independence and internal control information disclosure. They suggested that independent directors help to improve the quality of disclosure and increase the transparency of information. Ji et al., (2015, p.10) found a negative association between board independence and disclosure of internal control material weaknesses. They argued that more independent board can exert stronger monitoring over management and company's internal control system. Thus, companies with more independent board members are less likely to have ICMWs and thus are less likely to disclose ICMWs. However, (Krishnan, 2005, p.671; Zhang et al., 2007, p.320; Leng \&Yiran, 2011, p.286) found no association between board independence and disclosure of internal control material weaknesses. Therefore, the non-directional null hypothesis can be formulated as follow: 
H2: There is insignificant effect of board of directors' independence on the disclosure of ICMWs in the Egyptian environment.

\subsubsection{Role Duality.}

The Egyptian Code of Corporate Governance, (2016, p.12) stipulated that the board of director undertakes the designation of the chairperson and managing director. It is preferred that the two posts not be held by the same person. Should joining the posts be necessary, its reasons should be clarified in the company's annual report. In addition, a non-executive vice chairperson should be appointed and should also head the board meetings that discuss the performance of executive management.

There are two different views on board leadership structure. Agency theory advocates suggested that the roles of CEO and chairperson should be separated as combining the roles of CEO and chairperson is generally a sign of a dominant CEO and could render the board ineffective in monitoring managerial opportunistic behaviors (Daily and Dalton, 1993; Jensen, 1993). In contrary to agency theory, advocates of stewardship theory suggested that the interests of managers are aligned with those of the owners, and there is no inherent conflict of interest between the two. They also believed that role duality could promote a unified and strong leadership with a clear sense of strategic direction. Because the CEO had knowledge of the business and industry and knows how to run the company, combining these two roles can help in making timely and optimal decisions (Brickley et al.,1997).

The researchers agree with the rules stipulated in Egyptian Code of Corporate Governance and theoretical arguments of agency theory and suggests that chairperson and CEO functions should be performed by different persons to clearly separate between decision management (CEO) and decision control (chairperson) and to enhance directing, controlling and monitoring role of the board of director.

Previous studies examined the association between role duality and disclosure of internal control material weaknesses provided conflicting results. For instance, Mitra \& Hossain, $(2011$, p.5) found a positive significant relationship between non-role duality and remediation of internal control material weaknesses. They suggested that separation of $\mathrm{CEO} /$ Chairperson functions are more effective in monitoring management's actions to remediate internal control material weaknesses in a timely manner. Ji et al., $(2015$, p.12) found a positive association between role duality and disclosure of internal control material weaknesses. They suggested that the combined roles 
of CEO and chairperson weaken the board effectiveness in its monitoring over management and the company's internal control system thus, firms with combined roles of CEO and chairperson are more likely to have ICMWs and thus are more likely to disclose ICMWs. However, (Goh, 2009, p.566; Owusu-Ansah \& Ganguli, 2010, p.403) found no a significant association between role duality and disclosure and timely remediation of internal control material weaknesses. Therefore, the non-directional null hypothesis can be formulated as follow:

H3: There is insignificant effect of role duality on the disclosure of ICMWs in the Egyptian environment.

\subsubsection{Board of Directors' Diligence.}

Board meetings are platforms for discussing the performance and behavior of management apart from deciding on the strategic directions for the company. Directors on board discharge their responsibilities of control, monitoring and providing resource linkage through their active participation in the board meetings (Mishra \& Kapil, 2018).

According to the Egyptian Code of Corporate Governance, (2016, p.17) the board should meet at least once every three months. The number of board meetings should be disclosed in the company's annual report and board of director report. Meetings should consider the venue, timing, and arrangements that are convenient for the board members' attendance.

Previous studies examined the association between board diligence and disclosure of internal control material weaknesses provided similar results. For example, Zhang et al., (2007, p.320) found a positive association between board meetings and disclosure of internal control material weaknesses. They suggested that companies with internal control material weaknesses are more likely to hold additional meetings to deal with their internal control problems. Mitra \& Hossain, (2011, p.5) found also a positive significant relationship between board diligence and remediation of internal control material weaknesses. They indicated that board diligence motivates the firm's management to take immediate action to remediate internal control material weaknesses in order to reduce uncertainty surrounding the financial reporting process. Therefore, the non-directional null hypothesis can be formulated as follow:

H4: There is insignificant effect of board of directors' diligence on the disclosure of ICMWs in the Egyptian environment.

\subsection{Audit Committee Characteristics.}

An audit committee is considered as one of the dynamic monitoring mechanisms that firms should have to assist the board of

مجلة الاراسات التجارية المعاصرة


director in discharging its internal responsibilities and to enhance its effectiveness. The responsibilities of an audit committee include overseeing the financial reporting process ( Alfraih \& Almutawa, 2017, p.222 ) .

Several audit committee characteristics may influence the effectiveness of its monitoring and overseeing role. These characteristics include audit committee size, AC independence, AC financial expertise, and $\mathrm{AC}$ diligence. The current research examines the effect of those characteristics on the disclosure of internal control material weaknesses in the Egyptian setting as follows:

\subsubsection{Audit Committee Size.}

The number of audit committee members is normally used to measure the audit committee size, which is broadly considered as a crucial determinant of the audit committee (Hsu \& Petchsakulwong, 2010; Nuryanah, \& Islam, 2011; Obiyo \& Lenee, 2011). The Blue Ribbon Committee (1999) \& The Smith Report, (2003) recommended that an effective audit committee of listed companies should comprise at least three non-executive directors.

The Egyptian Code of Corporate Governance, (2016, p.23) also stipulated that audit committee is formed by non-executive and independent board members or from outside the company where at least one of them should have an accounting and financial expertise. The audit committee can comprise non-executive members if there is no a sufficient number of independent members.

Previous studies examined the relationship between audit committee size and disclosure of internal control material weaknesses provided mixed results. For instance, Goh, (2009, p.566) and Mitra et al., (2012, p.861) found a significant positive relationship between audit committee size and remediation of internal control material weaknesses in a timely manner. They indicated that a larger audit committee is more likely to question management and meet with internal control system personnel, which in turn speeds up the remediation of internal control material weaknesses (ICMWs). However, Zhang et al., (2007, p.320-321); Hoitash et al., (2009, p.853) found no a significant relationship between audit committee size and disclosure of internal control material weaknesses. Therefore, the non-directional null hypothesis can be formulated as follow:

H5:There is insignificant effect of audit committee size on the disclosure of ICMWs in the Egyptian environment.

\subsubsection{Audit Committee Independence.}

Corporate governance regulations are particularly concerned with audit committee independence. For instance, the Egyptian Code 
of Corporate Governance, (2016) stipulated that audit committee is formed by non-executive and independent board members or from outside the company. UK Corporate Governance Code, (2012) recommended that an audit committee is composed of a minimum of three independent directors. Blue Ribbon Committee, (1999); New York Stock Exchange (NYSE, 1999) and Sarbanes-Oxley Act of (2002) recommended that audit committees independence helps to ensure that management is transparent and is held accountable to stakeholders (BRC,1999).

Prior studies examined the association between audit committee independence and disclosure of internal control material weaknesses provided mixed results. For instance, Krishnan, (2005, p.671) found a significant negative relationship between audit committee independence and disclosure of internal control material weaknesses. She suggested that the greater the proportion of independent audit committee members, the less existence of internal control problems, and thus, are less likely to disclose ICMWs. OwusuAnsah \& Ganguli, (2010, p.403) found that there is a significant positive relationship between audit committee independence and voluntary reporting on the internal control system. They suggested that a large proportion of independent audit committee is better situated to assess objectively the quality of a company's financial disclosure and the adequacy of internal controls than a committee that is affiliated with management. Further, an independent audit committee with adequate resources helps to overcome management perquisites consumption and opportunistic behavior. Goh, (2009, p.566) found also a significant positive relationship between audit committee independence and remediation of internal control material weaknesses in a timely manner. He suggested that the more independent audit committee members, the more likely it is to question management on remediation efforts and meet with internal control system personnel., which in turn speed up the remediation of MWs. However, Zhang et al.,(2007, p.320) found no a significant relationship between audit committee independence and disclosure of internal control material weaknesses. Therefore, the non-directional null hypothesis can be formulated as follow:

H6: There is insignificant effect of audit committee independence on the disclosure of ICMWs in the Egyptian environment.

\subsubsection{Audit Committee Financial Expertise.}

In order to effectively monitor corporate financial reporting process, audit committee members should be financially literate, so that they are able to understand and interpret financial statements (Dhaliwal et al., 2010). 
Guides, professional bodies, and regulations are concerned about the financial expertise of audit committee members. For instance, the Egyptian Code of Corporate Governance, (2016) and The Blue Ribbon Committee on Improving the Effectiveness of Corporate Audit Committees (BRC)'s (1999) recommended that at least one of audit committee members should have adequate accounting and financial expertise highlights the importance of the financial literacy of audit committee members. Section 407 of the SOX also requires firms to disclose in periodic reports, whether a financial expert serves on a firm's audit committee and, if not, why not.

Previous studies that examined the relationship between audit committee financial expertise and disclosure of internal control material weaknesses provided mixed results. For instance, Stephens, (2011, p.126) and Ji et al., (2015, p.10) found a significant positive association between audit committee financial expertise and disclosure of internal control material weaknesses. They suggested that an audit committee with more accounting and financial experts can detect more internal control material weaknesses and thus, more likely to disclose ICMWs. Goh, (2009, p.566) and Mitra et al., (2012, p.861) found a significant positive relationship between the proportion of audit committee members having non-accounting financial expertise and remediation of internal control material weaknesses in a timely manner. They indicated that audit committees with greater nonaccounting financial expertise are more effective in monitoring the remediation of material weaknesses in the internal control system. However, Krishnan, (2005, p.671); Zhang et al., (2007, p.314); Krishnan \&Visvanathan, (2007); Ashbaugh- Skaife et al., (2007); Hoitash et al., (2009, p.853) found a significant negative relationship between audit committee financial expertise and disclosure of internal control material weaknesses. They indicated that audit committee members with more financial expertise are less likely to be associated with the existence of internal control problems. Therefore, the nondirectional null hypothesis can be formulated as follow:

H7:There is insignificant effect of audit committee financial expertise on the disclosure of ICMWs in the Egyptian environment.

\subsubsection{Audit Committee Diligence.}

Regulators have often expressed a strong preference for audit committee that meets frequently during the year (Barua et al., 2010). For instance, the Egyptian Code of Corporate Governance, (2016) and the Blue Ribbon Committee on audit committees in the USA setting, (1999) recommended that the audit committee should meet 
periodically at least once every three months with a specified agenda. The Guidance on Audit Committees in the UK, (2012) advocated that an audit committee should meet at least three times per year. The National Committee on Fraudulent Financial Reporting, commonly known as the Treadway Commission, (1987) recommended that an audit committee which intends to play a major role in oversight would need to maintain a high level of activity (Mohamad-Nor et al., 2010).

Prior studies that examined the relationship between audit committee diligence and disclosure of internal control material weaknesses provided mixed results. For instance, Hoitash et al., (2009, p.853); Owusu-Ansah \& Ganguli, (2010, p.403); Krishnan and Visvanathan (2007) found a significant positive relationship between frequent audit committee meetings and disclosure of internal control material weaknesses. They suggested that in the MWs context, more frequent audit committee meetings may be due to the discovery of problems in the internal control system, rather than increased diligence causing better control over financial reporting process. Khlif \& Samaha, (2016) and Huang et al., (2017) also found a significant positive relationship between audit committee activity and internal control quality. They suggested that an active audit committee may take several preventive remediation actions in a timely manner concerning internal control material weaknesses, which resulted in higher internal control quality. However, Zhang et al., (2007) found no a significant relationship between audit committee meetings and disclosure of internal control material weaknesses. Therefore, the non-directional null hypothesis can be formulated as follow:

H8: There is insignificant effect of audit committee diligence on the disclosure of ICMWs in the Egyptian environment.

\section{The Field Study:}

The objective of the field study is to investigate the effect of internal corporate governance mechanisms on the disclosure of internal control material weaknesses in the Egyptian environment. In order to achieve this objective, a self-administrated questionnaire was developed to collect the data of research.

\subsection{Population and Sampling of Research.}

The researchers identified the research population in five major categories. These categories include Executive officers, Financial officers, Internal auditors, Audit committee members, and External auditors working in different-size auditing firms. The sample is a subset of the entire population. Saunders et al. (2009, p. 213) distinguish between two sampling methods, namely the probability sampling and the non-probability sampling method. In the 
first one, each member of the sample has the equal chance of being chosen. Conversely, the second one does not use a random selection method, thus only a subset of the population is more likely to be included (Bryman \& Bell, 2011, p. 176). Moreover, probability sampling methods are common in quantitative studies, whereas nonprobability sampling methods are used in qualitative studies.

The sample of this research is represented in a judgmental non-probability sample of financial directors, executive directors, internal auditors, audit committee members, external auditors working in different-sized auditing firms.

Table ( 1 )

An Analysis of Responses by Respondent's Category.

\begin{tabular}{||c|c|c|c|c|c||}
\hline \multirow{2}{*}{ Category } & $\begin{array}{c}\text { No. of } \\
\text { Questionnaires } \\
\text { issued }\end{array}$ & \multicolumn{2}{|c|}{$\begin{array}{c}\text { No. of } \\
\text { Questionnaires } \\
\text { received }\end{array}$} & \multicolumn{2}{c||}{$\begin{array}{c}\text { No. of usable } \\
\text { questionnaires }\end{array}$} \\
\cline { 2 - 6 } & $\mathbf{N}$ & $\mathbf{N}$ & $\mathbf{\%}$ & $\mathbf{N}$ & $\%$ \\
\hline \hline 1. Executive Officer. & 40 & 37 & $92.5 \%$ & 34 & $85 \%$ \\
\hline 2. Financial Officer. & 40 & 35 & $87.5 \%$ & 29 & $72.5 \%$ \\
\hline 3. Internal Auditor. & 70 & 67 & $95.7 \%$ & 64 & $91.4 \%$ \\
\hline $\begin{array}{c}\text { 4. Audit committee } \\
\text { member. }\end{array}$ & 60 & 54 & $90 \%$ & 48 & $80 \%$ \\
\hline 5. Big 4. & 50 & 46 & $92 \%$ & 43 & $86 \%$ \\
\hline 6. Non-big 4. & 40 & 30 & $75 \%$ & 22 & $55 \%$ \\
\hline \hline Total & $\mathbf{3 0 0}$ & $\mathbf{2 6 9}$ & $\mathbf{8 9 . 7 \%}$ & $\mathbf{2 4 0}$ & $\mathbf{8 0 \%}$ \\
\hline
\end{tabular}

\subsection{Descriptive Analysis of Research Variables.}

After all responses have been checked to ensure the validity and excluding the items not sufficiently answered, all variables are coded according to the Statistical Package for Social Science (SPSS) version 21. For item coding, the researcher used Board Size, Board Ind1, Board Ind2, Role Duality, Board Meetings to refer to each subquestion of board of director characteristics, AC Size, AC Ind1, AC Ind2, AC Expertise, AC Meetings to refer to each sub-question of audit committee characteristics.

\subsubsection{Descriptive Analysis of the Demographic Profile of Respondents.}

It is important to introduce the background of respondents participating in the questionnaire that includes the education level, experience and professional certifications of the respondents to ensure that the collected data of the current research are reliable. Table (2) presents the descriptive analysis of the demographic profile of the respondents. 
Table (2) below shows that the majority of respondents that are involved in the research are internal auditors representing $26.7 \%$. It also shows that $20 \%$ of respondents are audit committee members, $17.9 \%$ are Big- $4,14.2 \%$ are executive officers, $12 \%$ are financial officers, $9.2 \%$ are non-big 4 .

The table also shows that $75 \%$ of the respondents have at minimum an undergraduate academic degree, $15.8 \%$ had a diploma in accounting and auditing, $7.1 \%$ had a master degree and $2.1 \%$ had $\mathrm{PhD}$ in accounting. It also shows that the respondents that are highly educated are Big-4, non-big 4, audit committee members, executive officers, financial officers and internal auditors respectively.

The table also shows that $47.1 \%$ of respondents have experiences more than 15 years, $31.25 \%$ have experience from 11 to 15 years, $18.8 \%$ have experience from 5 to 10 years, and $2.92 \%$ have experiences less than 5 years. This indicates that respondents involved in the research have a high level of experience and knowledge of the firm and its internal processes. It also showed that the respondents that have high experiences are audit committee members, internal auditors, financial officers, executive officers, Big-4 and non-big 4 respectively.

The table also shows that respondents that have professional certifications are Big 4 representing 35\%, audit committee members representing $22.2 \%$, internal auditors representing $17.5 \%$, non-big 4 representing $11.1 \%$, executive officers representing $9.5 \%$ and financial officers representing $4.8 \%$ respectively. 


\subsubsection{Descriptive Analysis of Independent Variables.}

Descriptive analysis is mainly used to describe and summarize the main features of the variables used in researches. It includes the frequencies, percentages, means, median, and standard deviation. The current research depends on frequencies and percentages only in describing the variables of research since the majority of research variables are categorical and computing mean, median, and standard deviation for those variables are meaningfulness ${ }^{1}$.

\section{Table ( 3 )}

Frequencies and Percentages of Board of Director Characteristics

\begin{tabular}{|l|c|c|c|}
\hline Board of Director Characteristics. & Frequency & Percentage \\
\hline \hline \multirow{3}{*}{ 1.Board Size. } & Less than 5 & 10 & 4.2 \\
\cline { 2 - 4 } & From 5 to 9 & 152 & 63.3 \\
\cline { 2 - 4 } & More than 9 & 78 & 32.5 \\
\hline \multirow{3}{*}{ 3. Board Ind1. } & Less than 5 & 151 & 63 \\
\cline { 2 - 4 } & From 5 to 9 & 89 & 37 \\
\hline 4. Role Duality. & Less than 5 & 111 & 46.3 \\
\cline { 2 - 4 } & From 5 to 9 & 110 & 45.8 \\
\cline { 2 - 4 } & More than 9 & 19 & 7.9 \\
\cline { 2 - 4 } & Yes & 199 & 82.9 \\
\hline 5. Board Meetings & No & 41 & 17.1 \\
\cline { 2 - 4 } & 4 times. & 11 & 4.6 \\
\cline { 2 - 4 } & 5 times. & 53 & 22.1 \\
\hline
\end{tabular}

\section{( Source : SPSS Vs. 21 Output )}

The above table (3) shows the frequencies and percentages of the board of director characteristics. With respect to Board of director's Size, approximately two-third of respondents $(63.3 \%)$ reveals that the number of directors on the board range from 5 to 9 while 78 of respondents $(32.5 \%)$ indicate that the number of board directors more than 9 members. This result reveals that the board of directors in the Egyptian listed companies compose of a sufficient number of directors that support carrying out its functions and responsibilities.

According to Board of director's Independence, approximately two-third of respondents $(63 \%)$ indicate that the number of executive directors on the board is less than 5 while 89 of

(1) Available at :

https://libguides.library.kent.edu/SPSS/FrequenciesCategorical.

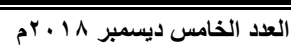


respondents $(37 \%)$ indicate that number of executive directors on the board range from 5 to 9 compared to 110 of respondents $(45.8 \%)$ indicate that the number of non-executive directors on the board range from 5 to 9 while 111 of respondents $(46.3 \%)$ indicate that the number of non-executive directors on the board is less than 5. These results reveal that the majority of board members in the Egyptian listed companies are non-executive directors and therefore, the board of director enjoy a considerable degree of independence in the Egyptian listed companies.

With respect to Role Duality, the majority of respondents $(82.9 \%)$ indicate that CEO is the same as managing director while a relatively low portion of respondents $(17.1 \%)$ indicate that both roles of CEO and managing director are separated. This result is consistent with the results of World Bank, (2004) that claims most of the chairmen of Egyptian firms are also CEOs.

With respect to Board Diligence, the vast majority of respondents $(95.4 \%)$ indicate that the number of meetings on the board is 5 times or more while a very low percentage of respondents $(4.6 \%)$ indicate that the number of board meetings is 4 and this result is consistent with the rules of Egyptian Code of Corporate Governance $(2011,2016)$ that stipulates the board should meet at least once every three months and this reveals that the board of director is active in the Egyptian listed companies.

Table ( 4 )

Frequencies and Percentages of Audit Committee Characteristics

\begin{tabular}{|l|c|c|c|}
\hline Board of Director Characteristics. & Frequency & Percentage \\
\hline \hline \multirow{2}{*}{ 6. AC Size. } & Less than 3 & 59 & 24.6 \\
\cline { 2 - 4 } & From 3 to 5 & 181 & 75.4 \\
\hline \multirow{3}{*}{ 7. AC Ind1. } & Less than 3 & 221 & 92.1 \\
\cline { 2 - 4 } & From 3 to 5 & 19 & 7.9 \\
\hline \multirow{3}{*}{ 8. AC Ind2. } & Less than 3 & 209 & 87.1 \\
\cline { 2 - 4 } & From 3 to 5 & 31 & 12.9 \\
\hline \multirow{3}{*}{ 9. AC Expertise. } & Less than 2 & 127 & 52.9 \\
\cline { 2 - 4 } & From 2 to 5 & 52 & 21.7 \\
\cline { 2 - 4 } & None & 61 & 25.4 \\
\hline \multirow{3}{*}{ 10. AC Meetings } & 4 times. & 19 & 8 \\
\cline { 2 - 4 } & 5 times. & 36 & 15 \\
\cline { 2 - 4 } & More than 5 times & 185 & 77.1 \\
\hline \hline
\end{tabular}

The above table shows the frequencies and percentages of the audit committee characteristics. With Respect to Audit Committee Size, slightly more than three- quarter of respondents (75.4\%) indicate 
that audit committee members range from 3 to 5 while approximately one-quarter $(24.6 \%)$ indicate that the members of the audit committee are less than 3. This result reveals that the audit committees in the Egyptian listed companies compose of an appropriate number of members.

With Respect to Audit Committee Independence, the vast majority of respondents $(92.1 \%, 87.1 \%)$ indicate that the number of non-executive directors and the independent directors on the audit committee is less than 3 .

With Respect to AC Financial Expertise, more than one-half of respondents $(52.9 \%)$ indicate that $\mathrm{AC}$ members with a financial expert are less than 2 while $21.7 \%$ of respondents indicate that $\mathrm{AC}$ members with a financial expert are from 2 to 5 . This result consistent with the rules of the Egyptian Code of Corporate Governance (2011, 2016) that stipulates at least one of the audit committee members should have adequate accounting and financial expertise.

With respect to Audit Committee Diligence, the vast majority of respondents $(92.1 \%)$ indicate that the number of AC meetings is 5 times or more while a relatively low portion of respondents $(8 \%)$ indicate that the number of $\mathrm{AC}$ meetings is 4 times and this result is consistent with the rules of Egyptian Code of Corporate Governance $(2011,2016)$ that stipulates the AC should meet at least once every three months with a specified agenda and this suggests that ACs in the Egyptian listed companies are active. 
The above table ( 5 ) shows the frequencies and percentages of existence and disclosure of internal control material weaknesses. To simplify the analysis, the internal control material weaknesses can be divided into two categories: account-specific MWs and companylevel MWs.

Account-Specific MWs :

1. With respect to the existence of inadequate controls for receivables, the majority of respondents $(83.3 \%, 80 \%)$ respectively reveal that it relates to lack of policies and procedures related to the collection of account receivables and inaccurate estimation of allowance for doubtful accounts compared to the disclosure of inadequate controls for receivables, more than two-third of respondents $(70.4 \%, 69.2 \%)$ respectively indicate that they disclose inaccurate estimation of allowance for doubtful accounts and inaccurate estimation of bad debt expense.

2. With respect to the existence of inadequate controls for income tax accounting, the majority of respondents $(81.7 \%, 80.4 \%)$ respectively indicate that it relates to improper reconciliation between the book and income tax and overstating income tax expense compared to the disclosure of inadequate controls for income tax accounting, approximately two-third of respondents $(68.3 \%, 65 \%)$ respectively indicate that they disclose improper reconciliation between the book and income tax and inaccurate estimation of deferred income tax.

3. With respect to the existence of inadequate controls for inventory transactions, the vast majority of respondents $(91.7 \%$, $87.5 \%)$ respectively indicate that it relates to obsolete inventories are not disposed and lack of policies and procedures related to physical inventory count compared to the disclosure of inadequate controls for inventory transactions, the majority of respondents $(82.5 \%)$ reveal that they disclose obsolete inventories are not disposed while approximately three-quarter (74.6\%) of respondents indicate that they disclose lack of policies and procedures related to physical inventory count.

4. With respect to the existence of insufficient controls over assets, the vast majority of respondents $(92.5 \%, 87.5 \%)$ respectively indicate that it relates to inaccurate estimation of useful lived tangible and intangible assets and the improper internal control over classification of some fixed asset balances compared to the disclosure of insufficient controls over assets, the majority of respondents $(82.9 \%)$ indicate that they disclose inaccurate estimation of useful lived tangible and intangible assets while 
slightly more than three-quarter of respondents $(78.3 \%)$ indicate that they disclose improper internal control over classification of some fixed asset balances.

\section{Company-Level MWs.}

5. With respect to the existence of Weaknesses in the period-end reporting process, the vast majority of respondents $(93.8 \%, 90.8 \%)$ respectively indicate that it relates to lack of proper interpretation and application of complex accounting standards and insufficient internal controls relating to the authorization, recognition, capture, and review of transactions, facts, circumstances, and events that could have a material impact on the company's financial reporting compared to the disclosure of Weaknesses in the period-end reporting process, the majority of respondents $(84.2 \%, 81.3 \%)$ respectively indicate that they disclose insufficient internal controls relating to the authorization, recognition, capture, and review of transactions, facts, circumstances, and events that could have a material impact on the company's financial reporting and lack of proper interpretation and application of complex accounting standards.

6. With respect to the existence of ineffective control environment, the vast majority of respondents $(92.9 \%, 82.9 \%)$ respectively indicate that it relates to inadequate assignment of authority and responsibility and lack of quality of corporate governance compared to the disclosure of ineffective control environment, the majority of respondents $(88.8 \%)$ indicate that they disclose inadequate assignment of authority and responsibility while approximately three-quarter of respondents $(74.6 \%)$ indicate that they disclose lack of quality of corporate governance.

7. With respect to the existence of lack of protection for privacy and security of information systems, the vast majority of respondents $(92.1 \%)$ indicate that it relates to back-up files are not stored in a secure, off-site locations while slightly three-quarter of respondents $(77.5 \%)$ indicate that it relates to firewalls, antivirus software, and other protective devices are not developed compared to the disclosure of lack of protection for privacy and security of information systems, the majority of respondents $(83.3 \%)$ indicate that they disclose back-up files are not stored in a secure, off-site locations while two-third of respondents $(71.7 \%)$ indicate that they disclose excessive access to systems and databases.

8. With respect to the existence of insufficient controls related to revenue recognition, the vast majority of respondents $(92.5 \%$, $85.4 \%$ ) indicate that it relates to weak internal controls related to 
contracting practices and inadequate controls related to the timing of revenue recognition compared to the disclosure of insufficient controls related to revenue recognition, the vast majority of respondents $(85.4 \%)$ indicate that they disclose weak internal controls related to contracting practices while two-third of respondents $(71.3 \%)$ indicate that they disclose weak internal controls related to the design and review of revenue recognition policies.

\subsection{Testing Hypotheses of Research.}

The first two proposed hypotheses were tested based on logistic regression. Logistic regression sometimes called the logistic model or logit model is a technique used to analyze the relationship between multiple independent variables and a categorical dependent variable and estimates the probability of occurrence of an event by fitting data to a logistic curve. There are two models of logistic regression, Binary Logistic Regression, and Multinomial Logistic Regression. Binary Logistic Regression is typically used when the dependent variable is dichotomous and the independent variables are either continuous or categorical. When the dependent variable is not dichotomous and is comprised of more than two categories, a Multinomial Logistic Regression can be employed (Hyeoun-Ae, 2013, p.155). So, the current research used Binary Logistic Regression since the dependent variable (the Disclosure of ICMWs) is dichotomous and the independent variables are categorical.

The last proposed hypothesis was tested based on the Kruskal-Wallis H Test (sometimes called the"One-Way ANOVA On Ranks") is a rank-based non-parametric test that can be used to determine if there are statistically significant differences between two or more groups of an independent variable on a continuous or ordinal dependent variable. It is considered the nonparametric alternative to the One-Way ANOVA, and an extension of the Mann-Whitney $U$ test to allow the comparison of more than two independent groups ${ }^{2}$.

\subsubsection{Developing the Proposed Index for the Disclosure of ICMWs:}

The statistical technique that is used to combine a group of related items in one index is the average method. That is each subindicator is calculated by adding the scores of questions which are related to this indicator, and then this sum is divided by the number of related questions. Then the final index that describes the disclosure of

\section{(2) Available at :}

https://statistics.laerd.com/.../kruskal-wallis-h-test-using-spss-statistics.

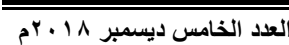


(ICMWs) is built by averaging all the sub-indicators and then median is calculated, and finally categorized into two categories whom median is less 0.8 reflects (no disclosure), and whom median is above 0.8 reflects (disclosure), and finally this index is used to predict the dependent variable (the disclosure of ICMWs) in the logistic regression model.

\subsubsection{Testing the First main Hypothesis.}

H1 : There is insignificant effect of the board of director characteristics on the disclosure of ICMWs in the Egyptian environment.

hypotheses:

This hypothesis can be answered by the following sub-

H11 : There is insignificant effect of board of directors' size on the disclosure of ICMWs in the Egyptian environment.

The results of this hypothesis are shown in the following tables.

Table ( 6 )

Categorical Variables Codings of Board of Directors' Size

\begin{tabular}{|c|c|c|c|c|}
\hline \multirow{2}{*}{} & \multirow{2}{*}{ Frequency } & \multicolumn{2}{|c|}{ Parameter coding } \\
\cline { 3 - 5 } \multicolumn{2}{|c|}{} & & $(1)$ & $(2)$ \\
\hline \hline \multirow{2}{*}{$\begin{array}{c}\text { Board } \\
\text { Size }\end{array}$} & less than 5 & 10 & 1.000 & .000 \\
& from 5 to 9 & 152 & .000 & 1.000 \\
& more than 9 & 78 & .000 & .000 \\
\hline
\end{tabular}

Source : SPSS Vs.21 Output.

The above table (5-6) shows the frequencies of board size and also shows the categories of board size have been recoded in the logistic regression model as dummy variables. This is done when the predictor variable is categorical. In order to make a comparison, one group has to be omitted from the comparison to serving as the baseline or the reference category $(\mathbf{R C})^{(3)}$. You can change the category to be used as the baseline to either first or last categories. So, it is clear that the RC for the board size is the last category (more than 9).

The goodness of the fitted model can be checked using different methods such as (chi-square test, classification tables, and Pseudo $\mathrm{R}^{2}$, and Hosmer-Lemeshow Test). The current research depended on the classification tables since it is the best in predicting the goodness of the fitted model ${ }^{(4)}$.

(3) Note that the reference category in all hypotheses of research is the last category. (4) Available at www.r-bloggers.com/evaluating-logistic-regression-models.

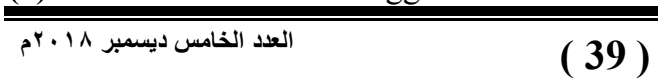

مجلة الدراسات التجارية المعاصرة 
Table (7)

Classification Table ${ }^{5}$ of Board of Directors' Size.

\begin{tabular}{|c|c|c|c|c|}
\hline & \multirow{3}{*}{ Observed } & \multicolumn{3}{|c|}{ Predicted } \\
\hline & & \multicolumn{2}{|c|}{$\mathbf{Y}$} & \multirow[b]{2}{*}{$\begin{array}{c}\text { Percentage } \\
\text { Correct }\end{array}$} \\
\hline & & $\begin{array}{c}\text { No } \\
\text { disclosure }\end{array}$ & Disclosure & \\
\hline Step 1 & $\begin{array}{c}\text { Yo disclosure } \\
\text { Disclosure } \\
\text { Overall Percentage }\end{array}$ & $\begin{array}{c}114 \\
48\end{array}$ & $\begin{array}{l}14 \\
64\end{array}$ & $\begin{array}{l}89.1 \\
57.1 \\
74.2\end{array}$ \\
\hline
\end{tabular}

The classification table (7) shows that $89.1 \%$ of responses of no disclosure is correctly classified as no disclosure, while $57.1 \%$ of responses of disclosure is correctly classified as disclosure. The overall classification is $74.2 \%$ which is higher than $50 \%$, and this indicates the high quality of the fitted model

Table (8)

Variables in the Equation of Board of Directors' Size.

\begin{tabular}{|cc|c|c|c|c|c|c|}
\hline & & B & S.E. & Wald & df & Sig. & $\operatorname{Exp(B)}$ \\
\hline \multirow{4}{*}{ Step 1 ${ }^{\mathrm{a}}$} & x11 (Board Size). & & & 49.162 & 2 & .000 & \\
& x11(1) & -1.925 & .710 & 7.359 & 1 & .007 & .146 \\
& x11(2) & -2.418 & .345 & 49.106 & 1 & .000 & .089 \\
& Constant & 1.520 & .295 & 26.534 & 1 & .000 & 4.571 \\
\hline
\end{tabular}

a. Variable(s) entered on step 1: x11.

the disclosure of ICMWs in the Egyptian environment, this at a significant level (P-value $0.000<0.05^{6}$ ) and confidence level $95 \%$.

* The table also shows the estimated logistic regression model in column headed (B) which is: $\operatorname{logit}(\mathrm{Y})=\alpha+\beta 1 \chi 1=1.520-1.925$ *board size1 - 2.418* board size2.

The table also gives $\operatorname{Exp}(\mathbf{B})$ which is known as the odds ratio predicted by the model. The odds of an event are the ratio of the probability that an event will occur to the probability that it will not occur. This odds ratio can be computed by raising the base of the natural $\log$ to the bth power, where $\boldsymbol{b}$ is the slope from the logistic regression equation ${ }^{7}$. Further, When $\operatorname{Exp}(\mathrm{B})$ is less than 1, this means increasing value of the variable correspond to

(5) The overall percentage of all classification tables in this research is higher than $50 \%$, and this indicates the goodness of the fitted model.

(6) The significance level of all tests conducted in this research is $(\mathrm{P}=0.05)$.

(7) Available at: http://core.ecu.edu/psyc/wuenschk/MV/Multreg/Logistic-SPSS.PDF. 
decreasing odds of the event's occurrence. When Exp (B) is greater than 1, this means increasing values of the variable correspond to increasing odds of the event's occurrence. when subtracting 1 from the odds ratio and multiply by 100, we get the percent change in odds of the dependent variable . $^{8}$

The table also shows that the odds of the disclosure of ICMWs for companies with the board of director less than 5 members are $85.4 \%$ which is less than those with the board of director more than 9 members (RC), this at a significant level (p-value) less than 0.05 and confidence interval $95 \%$. Further, the odds of the disclosure of ICMWs for companies with board members (from 5 to 9) is $91.1 \%$ which is less than those with board members more than 9 members, this at a significant level ( $p$-value) is less than 0.05 and confidence interval $95 \%$. So, the researchers can conclude that increasing number of members on the board will increase the probability of the disclosure of ICMWs in the Egyptian environment and this means that there is a significant positive effect of board size on the likelihood of disclosure of ICMWs in the Egyptian environment. This result implies that board of directors with more members are more effectively monitor management's assessments and reporting on the internal control system. Thus, companies with a large number of members are more likely to disclose ICMWs in the Egyptian environment. However, this result contradicts prior studies of (Zhang et al., 2007, p.320; Owusu-Ansah \& Ganguli, 2010, p.403; Ji et al., 2015, p.10; Yazawa, 2015, p.103), who found a negative effect of board size on the disclosure of ICMWs and prior studies of (Leng and Yiran, 2011, p.286; Kwame \& Mensah, 2016, p.90), who found no effect of board size on the disclosure of ICMWs. The reason behind this may be the different adopted environment or the time period in which the research was conducted.

Depending on the above results, the null hypothesis (H11) is not accepted and the alternative hypothesis is accepted which suggests that"There is a significant effect of board of directors' size on the disclosure of internal control material weaknesses in the Egyptian environment".

(8)Available at https://www.bgsu.edu/content/dam/BGSU/college-of-arts-andsciences/center-for-family-and-demographic-research/documents/Help-Resourcesand-Tools/Statistical\%20Analysis/Annotated-Output-Logistic-RegressionSPSS.pdf.

مجلة الاراسات التجارية المعاصرة


Table (9) : Variables in the Equation of Role Duality

\begin{tabular}{|cc|c|c|c|c|c|c|}
\hline & & B & S.E. & Wald & df & Sig. & $\operatorname{Exp(B)}$ \\
\hline \multirow{4}{*}{ Step $1^{\text {a }}$} & Executive $\mathbf{x 1 2 ~ ( 1 )}$ & 1.755 & .578 & 9.232 & 1 & .002 & 5.786 \\
& Non- executive x13 & & & 11.366 & 2 & .003 & \\
& $\mathbf{x 1 3 ( 1 )}$ & -1.881 & .716 & 6.898 & 1 & .009 & .152 \\
& x13 (2) & -.295 & .603 & .239 & 1 & .625 & .745 \\
& Constant & -.434 & .806 & .289 & 1 & .591 & .648 \\
\hline
\end{tabular}

The above table (5-9) shows that executive and non-executive members (that describe board independence) are significantly affected the disclosure of ICMWs in the Egyptian context, this at a significant level ( $p$-value $0.002<0.05$ ) and confidence interval $95 \%$.

* The table also shows the estimated logistic regression model which is: $\operatorname{Logit}(Y)=\alpha+\beta 2 \chi 2=\mathbf{- 0 . 4 3 4}+\mathbf{1 . 7 5 5} *$ board ind1 1.881 *board ind 2 .

* The table also shows the odds of the disclosure of ICMWs for companies with less than 5 executive members are 5.786 times higher than those with executive members from 5 to 9 , this at a significant level (the p-value) less than 0.05 and confidence interval 95\%. This means that board of directors with a low number of executive members has a high probability of the disclosure of ICMWs in the Egyptian environment. On the other hand, the odds of the disclosure of ICMWs for companies with less than 5 non-executive members is $84.8 \%$ which is less than those with more than 9 non-executive members, this at ( $\mathrm{p}$-value $<$ 0.05 ) and confidence interval $95 \%$. This implies that board of directors with a large number of non-executive members has a high probability of the disclosure of ICMWs in the Egyptian environment. Since board independence is measured by the number of non-executive directors. So, the researchers can conclude that there is a significant positive effect of board of directors' independence on the disclosure of ICMWs in the Egyptian environment. This result reveals that board of directors with more non-executive members effectively monitor and oversee the management's assessment and reporting on the internal control system. Thus, companies with more non-executive board members are more independent and thus, are more likely to disclose ICMWs. This result confirms prior studies of (OwusuAnsah \& Ganguli, 2010, p.403; Yazawa, 2015, p.103; Huang et al., 2017), who found a significant positive effect of board independence on the disclosure of ICMWs. However, it contrasts 
prior studies of ( $\mathrm{Ji}$ et al., 2015, p.10), who found a significant negative effect of board independence on the disclosure of ICMWs and (Krishnan, 2005, p.671; Zhang et al., 2007, p.320; Leng \& Yiran, 2011, p.286) who found no effect of board independence on the disclosure of internal control material weaknesses. The reason behind this may be the different adopted environment or the time period in which the research was conducted.

Based on the above results, the null hypothesis (H12) is not accepted and the alternative hypothesis is accepted which suggests that "There is a significant effect of board of directors' independence on the disclosure of ICMWs in the Egyptian environment".

Table (10)

Variables in the Equation of Role Duality

\begin{tabular}{|c|c|c|c|c|c|c|}
\hline & B & S.E. & Wald & df & Sig. & $\operatorname{Exp~(B)~}$ \\
\hline x 14(1) & 2.020 & .440 & 21.093 & 1 & .000 & 7.535 \\
& & & & & & \\
Constant & -.439 & .145 & 9.144 & 1 & .002 & .645 \\
\hline
\end{tabular}

a. Variable(s) entered on step 1: x14.

H13: There is insignificant effect of role duality on the disclosure of ICMWs in the Egyptian environment.

The result of this hypothesis is shown in the following table.

* The above table (5-10) shows that role duality is significantly affected the disclosure of ICMWs in the Egyptian environment, at a significant level $(p$-value $0.000<0.05)$ and confidence interval $95 \%$.

The table also shows the estimated logistic regression equation which is: $\operatorname{logit}(Y)=\alpha+\beta 3 \chi 3=-\mathbf{0 . 4 3 9}+2.020 *$ role duality.

The table also shows the odds of the disclosure of ICMWs for companies whose CEO is not the managing director is 7.535 times higher than the odds of those with CEO is the managing director, this at a significant level ( $\mathrm{p}$-value $<0.05$ ) and confidence interval $95 \%$. This means that companies whose CEO is not the chairman have a high probability for the disclosure of ICMWs in the Egyptian environment. So, the researchers can conclude that there is a significant negative effect of role duality on the disclosure of ICMWs in the Egyptian environment. This result implies that the combined role of managing director and CEO weaken board effectiveness in its monitoring role over management and the 
company's internal control system. Thus, companies with a combined role of managing director and chairperson are less likely to disclose ICMWs in the Egyptian setting. This result contradicts Ji et al., (2015, p.12) who found a significant positive effect of role duality on the disclosure of ICMWs. However, it contradicts (Owusu-Ansah \& Ganguli, 2010, p.403) who found no effect of role duality on the voluntary reporting on the internal control system. The reason behind this may be the different adopted environment or the time period in which the research was

The result of this hypothesis is shown in the following table.

Table (11)

Variables in the Equation of Board of Directors' Diligence.

\begin{tabular}{|c|c|c|c|c|c|c|}
\hline & B & S.E. & Wald & df & Sig. & $\operatorname{Exp(B)}$ \\
\hline x15 & & & 30.288 & 2 & .000 & \\
x15 (1) & -1.848 & .797 & 5.384 & 1 & .020 & .157 \\
x15 (2) & -2.227 & .434 & 26.380 & 1 & .000 & .108 \\
Constant & .344 & .153 & 5.063 & 1 & .024 & 1.411 \\
\hline
\end{tabular}

a. Variable(s) entered on step 1: x15.

conducted.

Based on the above results, the null hypothesis (H13) is not accepted and the alternative hypothesis is accepted which suggests that "There is a significant effect of role duality on the disclosure of ICMWs in the Egyptian environment".

\section{H14: There is insignificant effect of board of directors' diligence on the disclosure of ICMWs in the Egyptian environment.}

The above table (5-11) shows that board diligence is significantly affected the disclosure of ICMWs in the Egyptian environment, at a significant level $(p$-value $0.000<0.05)$ and confidence interval $95 \%$.

The table also shows the estimated model which is: $\operatorname{logit}(\mathbf{Y})=\boldsymbol{\alpha}+$ $\beta 4 \chi 4=0.344-1.848 *$ board meetings $1-2.227 *$ board meetings2.

The table also indicates the odds of the disclosure of ICMWs for companies whose board members meet 4 times is $84.3 \%$ which is less than those with board meetings more than 5 times, this at ( $p$ value $<0.05$ ) and confidence interval $95 \%$. In addition, the odds of the disclosure of ICMWs for companies whose board members meet 5 times are $89.2 \%$ which is less than those companies whose 
board members meet more than 5 times, this at a significant level (p-value $<0.05$ ) and confidence interval 95\%. This means that increasing number of board meetings increase the probability of the disclosure of ICMWs in the Egyptian setting. So, the researchers can conclude that there is a significant positive effect of board of directors' diligence on the Disclosure of ICMWs in the Egyptian environment. This result implies that an active board with more frequent board meeting contributes to board effectiveness in its monitoring role over the management and the company's internal control system. Thus, companies with more frequent board meetings are more likely to disclose ICMWs. This result is consistent with study of (Zhang et al., 2007, p.320) who found a positive effect of board meetings on the disclosure of internal control material weaknesses.

Based on the above results, the null hypothesis (H14) is not accepted and the alternative hypothesis is accepted which suggests that. "There is a significant effect of board_of directors' diligence on the disclosure of ICMWs in the Egyptian

Table (12)

Variables in the Equation of AC Size.

\begin{tabular}{|c|c|c|c|c|c|c|}
\hline & B & S.E. & Wald & df & Sig. & $\operatorname{Exp(B)}$ \\
\hline AC Size x21(1) & -1.706 & .366 & 21.707 & 1 & .000 & .182 \\
Constant & .233 & .150 & 2.425 & 1 & .119 & 1.263 \\
\hline
\end{tabular}

a. Variable(s) entered on step 1: x21.

environment".

\subsubsection{Testing the Second Main Hypothesis.}

H2: There is insignificant effect of audit committee characteristics on the disclosure of ICMWs in the Egyptian environment.

This hypothesis can be answered by the following subhypotheses:

H21: There is insignificant effect of audit committee size on the disclosure of ICMWs in the Egyptian environment.

The result of this hypothesis is shown in the following table.

The above table (5-12) shows that AC size is significantly affected the disclosure of ICMWs in the Egyptian environment, at a significant level ( $p$-value $0.000<0.05$ ) and confidence interval $95 \%$.

The table also shows the estimated model which is: $\operatorname{logit}(\mathbf{Y})=\boldsymbol{\alpha}+$ $\beta 5 \chi 5$

$=0.233-1.706 * \mathrm{AC}$ size.

مجلة الاراسات التجارية المعاصرة


The table also indicates that odds of the disclosure of ICMWs for companies whose audit committee members are less than 3 is $81.8 \%$ which is less than the odds of those with audit committee members are from 3 to 5 , this at ( $p$-value $<0.05$ ) and confidence interval 95\%. This means that increasing the number of audit committee members increase the probability of the disclosure of ICMWs in the Egyptian environment. So, the researchers can conclude that there is a significant positive effect of AC size on the Disclosure of ICMWs in the Egyptian environment. This result reveals that the audit committee with more members can exert strong monitoring on board's activities and financial reporting process and this can lead to more detection of internal control material weaknesses. Thus, companies with larger audit

Table (13)

Variables in the Equation of AC Independence.

\begin{tabular}{|c|c|c|c|c|c|c|}
\hline & B & S.E. & Wald & df & Sig. & $\begin{array}{c}\text { Exp } \\
\text { (B) }\end{array}$ \\
\hline x22 (1) Independent directors & -.594 & .487 & 1.486 & 1 & .223 & .552 \\
x23 (1) Non-executive directors & -.735 & .397 & 3.431 & 1 & .064 & .480 \\
Constant & 1.053 & .611 & 2.972 & 1 & .085 & 2.867 \\
\hline
\end{tabular}

a. Variable(s) entered on step 1: x22, x23.

committee are more likely to induce management to disclose ICMWs. However, this result contradicts (Zhang et al., 2007, p.321; Hoitash et al., 2009, p.853) who found no effect of audit committee size on the disclosure of internal control material weaknesses. The reason behind this may be the different adopted environment or the time period in which the research was conducted.

Based on the above results, the null hypothesis (H21) is not accepted and the alternative hypothesis is accepted which suggest that "There is a significant effect of AC size on the disclosure of ICMWS in the Egyptian environment".

H22: There is insignificant effect of audit committee independence on the disclosure of ICMWs in the Egyptian environment.

The result of this hypothesis is shown in the following table.

The above table (5-13) shows that non-executive members and independent members (which describe $\mathrm{AC}$ independence) are not significantly affected the disclosure of internal control material weaknesses in the Egyptian environment since the p-value is greater than $0.05 \%$ at confidence interval $95 \%$. 
Table (14)

Variables in the Equation of AC Financial Expertise.

\begin{tabular}{|c|c|c|c|c|c|c|}
\hline & B & S.E. & Wald & df & Sig. & $\begin{array}{c}\text { Exp } \\
\text { (B) }\end{array}$ \\
\hline AC Expertise & & & 33.740 & 2 & .000 & \\
X24 (1) & 1.435 & .377 & 14.462 & 1 & .000 & 4.201 \\
X24 (2) & 2.718 & .468 & 33.698 & 1 & .000 & 15.152 \\
Constant & -1.514 & .333 & 20.671 & 1 & .000 & .220 \\
\hline
\end{tabular}

a. Variable(s) entered on step 1: x24.

This result is consistent with Zhang et al.,(2007, p.320) who found no effect of audit committee independence on the disclosure of internal control material weaknesses. However, it contrasts prior studies of (Krishnan, 2005, p.671who found a negative effect of audit committee independence on the disclosure of internal control material weaknesses and Owusu-Ansah \& Ganguli, (2010, p.403) who found a positive effect of audit committee independence on voluntary reporting on the internal control system. The reason behind this may be the different adopted environment or the time period in which the research was conducted. So, the researchers can accept the null hypothesis (x22) which suggests that " There is insignificant effect of audit committee independence on the disclosure of internal control material weaknesses in the Egyptian environment".

H23: There is insignificant effect of audit committee financial expertise on the disclosure of ICMWs in the Egyptian environment.

The result of this hypothesis is shown in the following table.

The above table (5-14) shows that AC financial expertise is significantly affected the disclosure of ICMWs in the Egyptian environment, at a significant level (p-value $0.000<0.05)$ and confidence interval $95 \%$.

The table also shows the estimated model of AC expertise which is: $\operatorname{logit}(\mathrm{Y})=\alpha+\beta 6 \chi 6=-1.514+1.435 * \mathrm{AC}$ expertise $1+2.718^{*}$ AC expertise2.

The table also shows that odds of the disclosure of ICMWs for companies whose audit committee have less than 2 financial expert members are 4.2 times higher than the odds of those that have no financial experts, this at a significant level ( $p$-value) is less than 0.05 and confidence interval $95 \%$. Further, the odds of the disclosure of ICMWs for companies whose audit committee have from 2 to 5 members with financial expertise are 15.15 which 
is higher than the odds of those who have no financial experts, this at $(p$-value $<0.05)$ and confidence interval 95\%. This means that increasing the number of the audit committee members with financial expertise increase the probability of the disclosure of ICMWs in the Egyptian setting. So, the researchers can conclude that there is a significant positive effect of AC financial expertise on the disclosure of ICMWs in the Egyptian environment. This result implies that audit committees with more financial expertise members can exert strong monitoring on board's activities and the financial reporting process and this can lead to more detection of internal control material weaknesses. Thus, companies with more audit committee members with financial expertise are more likely to induce management to disclose ICMWs in the Egyptian setting. This result confirms prior studies of (Stephens, 2011, p.126 and Ji et al., 2015, p.12) who found a positive effect of audit committee financial expertise on the disclosure of internal control material weaknesses. However, it contradicts (Krishnan, 2005, p.671; Zhang et al., 2007, p.314; Krishnan \&Visvanathan, 2007; Ashbaugh- Skaife et al., 2007; Hoitash et al., 2009, p.853) who found a negative effect of audit committee financial expertise on the disclosure of internal control material weaknesses. The reason behind this may be the different adopted environment or the time period in which the research was conducted.

Based on the above results, the null hypothesis (H24) is not accepted and the alternative hypothesis is accepted which suggests that "There is a significant effect of $\mathrm{AC}$ financial expertise on the disclosure of ICMWs in the Egyptian environment".

H24: There is insignificant effect of audit committee diligence on the disclosure of ICMWs in the Egyptian environment.

Table (15)

Variables in the Equation of AC Diligence.

\begin{tabular}{|c|c|c|c|c|c|c|}
\hline & B & S.E. & Wald & df & Sig. & $\begin{array}{c}\text { Exp } \\
\text { (B) }\end{array}$ \\
\hline AC diligence x25 & & & 24.248 & 2 & .000 & \\
x25 (1) & -1.924 & .646 & 8.860 & 1 & .003 & .146 \\
x25 (2) & -2.074 & .504 & 16.928 & 1 & .000 & .126 \\
Constant & .250 & .148 & 2.845 & 1 & .092 & 1.284 \\
\hline
\end{tabular}

a. Variable(s) entered on step 1: x25.

The results of this hypothesis are shown in the following table. 
The above table (5-15) shows that AC diligence is significantly affected the disclosure of ICMWs in the Egyptian setting, at a significant level ( $p$-value $0.000<0.05)$ and confidence interval $95 \%$.

The table also shows the regression equation of $\mathrm{AC}$ diligence which is:

$$
\operatorname{logit}(\mathrm{Y})=\alpha+\beta 7 \chi 7=\underset{\text { meetings } 2 .}{0.250-1.924 * A C} \text { meetings1- } 2.074 * \mathrm{AC}
$$

* The table also shows the odds of the disclosure of ICMWs for companies whose AC members meet 4 times is $85.4 \%$ which is less than the odds of those with AC members meet more than 5 times, this at a significant level (p-value) less than 0.05 and confidence interval $95 \%$. In addition, the odds of the disclosure of ICMWs for companies whose AC members meet 5 times is $87.4 \%$ which is less than the odds of those who AC members meet more than 5 times, this at a significant level (p-value) is less than 0.05 and confidence interval $95 \%$. This means that increasing number of AC meetings increase the probability of the disclosure of ICMWs in the Egyptian environment. So, the researchers can conclude that there is a significant positive effect of $\mathrm{AC}$ diligence on the disclosure of ICMWs in the Egyptian environment. This result implies that companies with more frequent $\mathrm{AC}$ meetings effectively monitor the internal control system and financial reporting process. Thus, companies with more frequent audit committee meetings are more likely to induce management to disclose ICMWs. This result is consistent with prior studies of (Hoitash et al., 2009, p.853; Owusu-Ansah \& Ganguli, 2010, p.403; Krishnan and Visvanathan 2007) who found a positive effect of frequent audit committee meetings on the disclosure of internal control material weaknesses. The reason behind this may be the different adopted environment or the time period in which the research was conducted.

* Based upon the above results, the null hypothesis (H25) is not accepted and the alternative hypothesis is accepted which suggests that "There is a significant effect of AC diligence on the disclosure of ICMWs in the Egyptian environment".

\subsubsection{Testing the Third Hypothesis.}

H3: There are insignificant differences among respondents' perceptions of the disclosure of ICMWs in the Egyptian environment.

The results of this hypothesis are shown in the following tables. 
Table (16)

Results of Kruskal-Wallis Test Regarding the Items of the Disclosure of ICMWs.

\begin{tabular}{|l|c|c|c|}
\hline \multicolumn{1}{|l|}{ Internal Control Material Weaknesses (ICMWs) } & $\begin{array}{c}\text { Chi- } \\
\text { Square }\end{array}$ & DF & Sig \\
\hline $\begin{array}{l}\text { 1. Inadequate controls with respect to accounting for } \\
\text { receivables. }\end{array}$ & 6.388 & 5 & 0.270 \\
\hline 2. Inadequate controls for income tax accounting. & 8.41 & 5 & 0.135 \\
\hline 3. Inadequate controls for inventory transactions. & 6.17 & 5 & 0.290 \\
\hline 4. Insufficient controls over assets. & 16.95 & 5 & 0.005 \\
\hline 5. Weaknesses in the period-end reporting process. & 13.83 & 5 & 0.017 \\
\hline $\begin{array}{l}\text { 6. Ineffective control environment. } \\
\text { 7. Lack of protection for privacy and security of } \\
\text { information systems. }\end{array}$ & 7.99 & 5 & 0.157 \\
\hline $\begin{array}{l}\text { 8. Insufficient controls related to revenue recognition. } \\
\text { 9. Improper accounting for derivatives. }\end{array}$ & 11.9 & 5 & 0.051 \\
\hline $\begin{array}{l}\text { 10. Improper accounting for accruals such as prepaid } \\
\text { expenses and accrued expenses. }\end{array}$ & 5.958 & 5 & 0.036 \\
\hline $\begin{array}{l}\text { 11.Lack of qualified personnel and training in } \\
\text { accounting, finance or information systems. }\end{array}$ & 6.498 & 5 & 0.261 \\
\hline 12. Lack of segregation of duties. & 6.946 & 5 & 0.225 \\
\hline 13. Inconsistent application of accounting policies. & 3.604 & 5 & 0.608 \\
\hline $\begin{array}{l}\text { 14. Inconsistencies in the application of company } \\
\text { policies among business units and segments. }\end{array}$ & 4.209 & 5 & 0.520 \\
\hline (Source SPSS Vs.21 Output) & 5 & 0.064 \\
\hline
\end{tabular}

(Source: SPSS Vs.21 Output).

The results of the Kruskal-Wallis test shown in the table (16) revealed insignificant differences among the respondents' perceptions on the items of the disclosure of ICMWs $^{9}$, except for 3 items: insufficient controls over assets $(\mathrm{P}=0.005)$, weakness in the periodend reporting process $(\mathrm{P}=0.017)$, insufficient controls related to revenue recognition $(\mathrm{P}=0.036)$.

Table (17)

Results of Kruskal-Wallis Test Regarding the Disclosure of ICMWs ${ }^{10}$

\begin{tabular}{|c|c|}
\hline & The Disclosure of ICMWs (Y) \\
\hline Chi-Square & 5.287 \\
\hline Df & 5 \\
\hline Asymp. Sig. & .382 \\
\hline
\end{tabular}

( Source: SPSS Vs.21 Output).

(9) The grouping variable is the current position.

(10) The dependent variable is used in the original form before dividing it into two categories. 
The above table (17) shows that there are insignificant differences among the respondents' perceptions on the disclosure of internal control material weaknesses in the Egyptian environment since the $(p$-value $=0.382)$ is greater than 0.05 . Based upon the above results, the null hypothesis (H5) is accepted which suggests that "There are insignificant differences among respondents' perceptions on the disclosure of internal control material weaknesses in the Egyptian environment".

\section{Research Summary, Results, and Recommendations. 6.1 Research Summary and Results.}

This research intends to explore the effect of internal corporate governance mechanisms with particular reference to (board of directors and audit committee) on the disclosure of internal control material weaknesses in the Egyptian environment. In order to achieve this objective, the research is consisted of two main streams. The first covered the theoretical part of research while the second covered the empirical part to test the research hypotheses. The current research provided some theoretical and practical results that can be discussed as follows:

\subsubsection{Theoretical Results:}

1. Disclosure of ICMWs provides an early warning for firms about potential future accounting problems and crises that may adversely affect the credibility and transparency of financial reporting.

2. Disclosure of ICMWs helps companies to establish an effective control environment to prevent fraud, misdirection of corporate resources, and opportunistic actions by managers which resulted in more reliable and transparent financial reporting and thus, better corporate governance practices.

3. ICMWs are classified into two major types: Account-Specific MWs and Company-Level MWs. However, the company-level MWs are the most type of MWs existed in the Egyptian listed companies.

4. Internal Corporate governance mechanisms with particular reference to (board of director and audit committee) are crucial determinants of disclosure of ICMWs in the Egyptian environment.

\subsubsection{Practical Results:}

6. With respect to the first main hypothesis, the results revealed that there are significant positive effects of board of directors' size, board of directors' independence, board of directors' diligence on the likelihood of disclosure of ICMWs in the Egyptian environment. However, there is a significant negative effect of role duality on the likelihood of disclosure of ICMWs in the Egyptian environment.

مجلة الاراسات التجارية المعاصرة


7. With respect to the second main hypothesis, the results revealed that there are significant positive effects of AC size, AC financial expertise, and AC Diligence on the likelihood of disclosure of ICMWs in the Egyptian setting. However, there is no a significant effect of $\mathrm{AC}$ independence on the disclosure of ICMWs in the Egyptian environment.

8. With respect to the third hypothesis, the results revealed that there are insignificant differences among the respondents' perceptions on the disclosure of internal control material weaknesses in the Egyptian environment since the $(p$-value $=0.382)$ is greater than 0.05 .

\subsection{Recommendations for Research.}

Based on the research results about the effect of internal corporate governance mechanisms on the disclosure of internal control material weaknesses in the Egyptian environment, the researchers recommend the following:

1. Egyptian legislations and laws should be issued to require the Egyptian listed companies to disclose internal control material weaknesses such as SOX in America, J-SOX in Japan, and Basic Standard in China.

2. Egyptian Auditing Standards should be issued to address the audit of internal control over financial reporting such as Auditing Standards issued by PCAOB, AICPA.

3.The research recommends that the disclosure of internal control material weaknesses (ICMWs) should be mandatory on the companies listed on the Egyptian Stock Exchange (EGX).

4. The research recommends EFSA to hold conferences to inform investors and all stakeholders about the importance of preparing reports on the effectiveness of internal control system.

5. The research recommends the management of Egyptian listed companies to disclose the remedial actions taken concerning the material weaknesses in internal control over financial reporting in a timely manner to restore the investor confidence in the financial reporting.

6. The research recommends the Egyptian listed companies to comply with the rules and principles stipulated in the Egyptian Code of Corporate Governance 2016 to enhance the disclosure and transparency policy and thus, enhance the credibility and reliability of financial reporting.

7.The Egyptian listed companies need to concentrate more on the components of internal control system in order to enhance and promote the overall control environment.

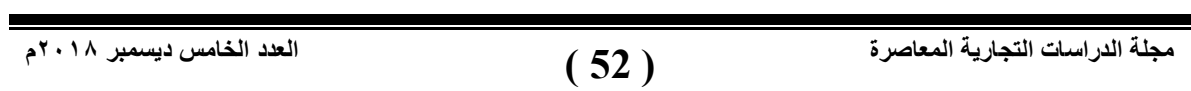




\section{References}

1- Egyptian Institute of Directors, Egyptian Financial Supervisory Authority, (2016)." The Egyptian Code of Corporate Governance". Available at http://www.EFSA.com.

2- Samy Mohamed Ghoneimy, (2013)." The Positive Extent of Financial Crisis in Activating the Principles of Corporate Governance in Business Organizations- Analytical Study", Egyptian Journal of Commercial Studies, Faculty of Commerce, Mansoura University, Vol.37, No.2, pp: 95-154.

3- Alfraih, M.M., Almutawa, A.M. (2017). "Voluntary Disclosure and Corporate Governance: Empirical Evidence from Kuwait", International Journal of Law and Management, Vol. 59, No. 2, pp.217-236.

4- Ashbaugh-Skaife, H., Collins, D.W. and Kinney, W. (2007), "The Discovery and Reporting of Internal Control Deficiencies prior to SOX-Mandated Audits", Journal of Accounting and Economics, Vol. 44, No.1/2, pp:166-92.

5- ------, (2009). " The Effect of SOX Internal Control Deficiencies on Firm Risk and Cost of Equity", Journal of Accounting Research, Vol.47, Nol.1, pp:1-43.

6- Blue Ribbon Report, (1999). "Report and Recommendations of the Blue Ribbon Committee on Improving the Effectiveness of Corporate Audit Committees", New York, NY: New York Stock Exchange and the National Association of Securities Dealers.

7- Barua, A., Rama, D., \& Sharma, V. (2010). "Audit Committee Characteristics and Investment in Internal Auditing", Journal of Accounting and Public Policy, Vol.29, No.5, pp:503-513.

8- Boritz, J.E., Hayes, L. and Lim, J.H. (2013), "A content analysis of auditors' reports on IT internal control weaknesses: the comparative advantages of an automated approach to control weakness identification", International Journal of Accounting Information Systems, Vol.14, No.2, pp. 138-163.

9- Bryman, B. and Bell, E. (2011), "Business Research Methods", 3rd ed., Oxford: Oxford University Press.

10-Desoky, A.M. and Mousa, G.A. (2012),"Corporate Governance Practices: Transparency and Disclosure- Evidence from the Egyptian Exchange", Journal of Accounting, Finance and Economics, Vol.2, No.1, pp.49-72.

11-Doyle, J., Ge, W., \& McVay, S.(2007a). "Determinants of Weakness in Internal Control over Financial Reporting", Journal of Accounting and Economics, Vol.44, No.1-2 pp:193-223. 
12-Doyle, J., Ge, W., \& McVay, S. (2007b)." Accruals Quality and Internal Control over Financial Reporting", Accounting Review, Vol.82, No.5, pp:1141-1170.

13-El-Diftar, D. (2016)."Institutional Investors and Voluntary Disclosure and Transparency in Egypt", PHD Thesis, Cardiff Metropolitan University.

14-Ezat, A \& El-Masry, A. (2008)."The Impact of Corporate Governance on the Timeliness of Corporate Internet Reporting by Egyptian Listed Companies", Managerial Finance, Vol.34, No.12, pp: 848-867.

15- Financial Reporting Council (FRC), (2008), "Guidance on Audit Committees", London: FRC.

16---------, (2012), " Guidance on Audit Committees", FRC, London, available at: www.frc.org.uk.

17-Ge, W. \& Mcvay, S.(2005)."The Disclosure of Material Weaknesses in Internal Control after The Sarbanes- Oxley Act", Accounting Horizons, Vol.19, No.3, pp: 137- 158.

18-Goh, B. (2009)."Audit Committees, Boards of Directors, and Remediation of Material Weaknesses in Internal Control", Contemporary Accounting Research, Vol.26, No. 2, pp: 549-579.

19-Haislip, J., Masli, A., Richardson, V.J. \& Watson, M.W.(2015)."External Reputational Penalties for CEOs and CFOs Following Information Technology Material Weaknesses", International Journal of Accounting Information Systems, Vol.17, pp: 1-15.

20-Hoitash, U., Rani, H \& Jean, B.C. (2009)."Corporate Governance and Internal Control over Financial Reporting: A comparison of Regulatory Regimes", The Accounting Review, Vol.84, No.3, pp. 839-867.

21-Huang, F., Chen, J., Ma, H \& Hou, Q. (2017)."Analysis of the Information Disclosure of Commercial Banks Internal Control", International Journal of Economics and Finance, Vol.9, No.5, pp. 77-86.

22-Hsu, W., \& Petchsakulwong, P. (2010). "The Impact of Corporate Governance on the Efficiency Performance of the Non-Life Insurance Industry", The Geneva Papers on Risk and Insurance Issues and Practice, Vol.35, No.1, pp. 28-49.

23-Hyeoun-Ae, P.(2013)." An Introduction to Logistic Regression from Basic Concepts to Interpretation with Particular Attention to Nursing Domain ", J Korean Acad Nurs, Vol. 43, No. 2, pp.154-164. 
24-Ji, X., Wei, L \& Wen, Q.(2015)."Determinants and Economic Consequences of Voluntary Disclosure of Internal Control Weaknesses in China", Journal of Contemporary Accounting \& Economics, Vol.11, No.1, pp: 1-17.

25-----------, (2016). " Internal Control Weakness and Accounting Conservatism in China", Managerial Auditing Journal, Vol.31, No.6/7, pp:688-726.

26--------------------, (2017). " Voluntary Disclosure of Internal Control Weakness and Earnings Quality: Evidence from China", The International Journal of Accounting, Vol.52, No.1, pp.27-44.

27- Jin, L., and Myers, S.C. (2006). "R2 around the world: new theory and new tests", Journal of Financial Economics, Vol.79, pp. 257-292.

28-Karamanou, I. and Vafeas, N. (2005)."The Association Between Corporate Boards and Audit Committees with Management Earnings Forecasts: An empirical Analysis", Journal of Accounting Research, Vol.43, No.3, pp:453-486.

29-Khlif., H \& Samaha, K. (2016)."Audit Committee Activity and Internal Control Quality in Egypt", Managerial Auditing Journal, Vol. 31, No.3, pp. $269-289$.

30-Kim, J.B., Li, Y and Zhang, L. (2011) a. "CFOs versus CEOs: Equity Incentives and Crashes", Journal of Financial Economics, Vol.101, pp:713-730.

31-Kim, J. B., and Zhang, L.D. (2014). "Financial Reporting Opacity and Expected Crash Risk: Evidence from Implied Volatility Smirks", Contemporary Accounting Research, Vol. 31, pp. 851-875.

32-Kim, J., Yeung, I \& Zhou, J.(2017)." Stock Price Crash Risk and Internal Control Weakness: Presence vs. Disclosure Effect", Accounting \& Finance, pp: 1-37.

33-Krishnan, G.V. and Visvanathan, G.(2007)."Reporting Internal Control Deficiencies in the Post-Sarbanes-Oxley Era: The Role of Auditors and Corporate Governance", International Journal of Auditing, Vol.11, No.2, pp.73-90.

34-Krishnan, J. (2005). "Audit Committee Quality and Internal Control: An empirical Analysis", The Accounting Review, Vol.80, No.2, pp. 649-675.

35-Kwame, B \& Agyei, M. (2016)."Internal Control Information Disclosure and Corporate Governance: Evidence from an Emerging Market", Corporate Governance, Vol. 16, No.1, pp. 79-95. 
36-Kwame, B \& Agyei, M. (2017)."The Relationship Between Corporate Governance Mechanisms and IFRS 7 Compliance: Evidence from an Emerging Market", Corporate Governance: The International Journal of Business in Society, Vol.17, No.3, Available at doi:10.1108/CG-06-2016-0129.

37-Leng, J \& Yiran, D. (2011)."Internal Control Disclosure and Corporate Governance: Empirical Research from Chinese Listed Companies", Technology and Investment, Vol.2, No.4, pp. 286-294.

38-Li, W., Phang, S \& Ho, S.(2017)." CEO/CFO Turnover and Subsequent Remediation of Information Technology Material Weaknesses, Accounting \& Finance, pp:1-25.

39-Mangena, M., \& Pike, R. (2005). "The Effect of Audit Committee Shareholding, Financial Expertise and Size on Interim Financial Disclosures", Accounting and Business Research, Vol.35, No.4, pp. 327-349.

40-Mitra, S \& Hossain, M. (2011)."Corporate Governance Attributes and Remediation of Internal Control Material Weaknesses Reported under SOX Section 404", Review of Accounting and Finance, Vol.10, No.1, pp: 5-29.

41- ----------, \& Marks, B.R. (2012)."Corporate Ownership Characteristics and Timeliness of Remediation of Internal Control Weaknesses", Managerial Auditing Journal, Vol. 27, No.9 pp. $846-877$.

42-Mishra, R. and Kapil, S. (2018),"Board Characteristics and Firm Value for Indian Companies", Journal of Indian Business Research, https://doi.org/10.1108/JIBR-07-2016-0074.

43-Mohamed-Nor, M.N., Shafie, R. and Wan-Hussin, W.N. (2010)."Corporate Governance and Audit Report Lag in Malaysia", Asian Academy of Management Journal of Accounting and Finance, Vol.6, No.2, pp.57-84.

44-Moody's Investors Service, (2004), (2006), (2007). "First year, Second Year, and Third Year Section 404 Reports on Internal Control: Impact on Ratings Depend on Nature of Material Weaknesses Reported". New York, NY.

45-New York Stock Exchange and the National Association of Securities Dealers," Blue Ribbon Committee on Improving the Effectiveness of Corporate Audit Committees", (1999), p.11 Available at www.nasdaq.com.

46-Nuryanah, S., \& Islam, S. M. N. (2011). "Corporate Governance and Performance: Evidence from an Emerging Market", Malaysian Accounting Review, Vol.10, No.1, pp.17-42. 
47-Obiyo, O. C., \& Lenee, L. T. (2011). "Corporate Governance and Firm Performance in Nigeria", IJEMR, Vol.1, No.4, pp. 1-12.

48-Owusu-Ansah, S \& Ganguli, G. (2010)."Voluntary Reporting on Internal Control Systems and Governance Characteristics: An Analysis of Large U.S. Companies", Journal of Managerial Issues, Vol. XXII, No.3, pp: 383- 408.

49-PCAOB, (2015)."An Audit of Internal Controls Over Financial Reporting That is Integrated with An Audit of Financial Statements ", Auditing Standard No.2201, Public Company Accounting Oversight Board, Washington, DC.

50-Saunders, M.N., Saunders., M., Lewis, P and Thornhill, A. (2011). "Research Methods for Business Students", 5/E: Pearson Education India.।

51-Saunders, M., Lewis, P. and Thornhill, A. (2009),"Research Methods for Business Students", Prentice Hall Edinburgh Gate $5^{\text {th }}$ edition.

52-Smith Report, (2003). "Audit Committees: Combined Code Guidance. London: Financial Reporting Council", Available at www.frc.org.uk/publications.

53-Sorour, M.K. (2014), "Corporate Governance Reform in Egypt: Achievements and Challenges Ahead, in book", Corporate Governance: An International Perspective, Chapter 8, S.O. Idowu and K.T. Caliyurt (editors), Springer, pp.143-155. DOI 10.1007/978-3-642-45167-6 8.

54-Stephens, N.M. (2009). "Corporate Governance Quality and Internal Control Reporting under SOX Section 302", Jon M. Huntsman School of Business", Available at http://ssrn.com/abstract $=1313339$.

55-----------------, (2011)."External Auditor Characteristics and Internal Control Reporting under SOX Section 302", Managerial Auditing Journal, Vol. 26, No.2 pp. 114-129.

56-Treadway Commission, (1987). "Report of the National Commission on Fraudulent Financial Reporting".

57-Transparency International (2015), "Corruption Perceptions Index 2015", Transparency International: the global coalition against corruption. Available from: <www.transparency.org $>$. [15 June 2016].

58- US House of Representatives (2002), "The Sarbanes-Oxley Act of 2002" Public Law 107-204 (H.R.3763), Government Printing Office, Washington, DC. Available at: https://www.sec.gov/about/laws/soa2002.pdf. 
59- Yazawa, K. (2015)." The Incentive Factors for the (Non-) disclosure of material weakness in internal control over financial reporting: evidence from J- SOX mandated audits", International Journal of Auditing, Vol. 19, pp. 103-116. Available at : doi:10.1111/ijau.12035.

60-Zhang, Y., Zhou, J., \& Zhou, N.(2007)."Audit Committee Quality, Auditor Independence, and Internal Control Weaknesses", Journal of Accounting and Public Policy, Vol. 26, No.3, pp. 300-327. 


\title{
Research Appendix:
}

\author{
Kafrelsheikh University \\ Faculty of Commerce \\ Accounting Department
}

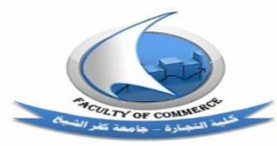

\section{Dear Sir :}

The researchers prepare a research in accounting titled "The Effect of Internal Corporate Governance Mechanisms on the Disclosure of Internal Control Material Weaknesses". Since the objective of the scientific research can only be achieved through a sound correlation between the scientific principles and the practical life, the researchers would like to know your valuable points of view regarding the subject of this research as this will surely enhance the results and overall the value of this research. Kindly note that all your responses will be treated with confidentiality and will be used for research purposes only. Please accept in advance best regards from the researchers and appreciation for your cooperation.

\section{Researchers}

Prof. Hly Mogahed Hhmed Hlsayed

Associate Professor of Accounting \& Chairman of Accounting Department

Faculty of Commerce

Kafrelsheikh University
Dr. Ayman Mohamed Sabry

Lecturer at Accounting Department

Faculty of Commerce

Kafrelsheikh University

\section{Hadeer Metwally Rashad Metwally \\ Demonstrator at Accounting Department \\ Faculty of Commerce \\ Kafrelsheikh University}


First: The Demographic Profile of Respondent.

1. Name (Optional):

2. Your Educational Level:
Bachelor.
Diploma in Accounting and Auditing.
Master.
$\mathrm{PhD}$.

\section{Professional Certifications:}

\section{Your Current Position:}

Financial Officer.

Internal Auditor.

Audit Committee

Member.

$\square$ Executive Officer.

4. Your organization:

\section{Years of Experience:}

$\square$ less than 5 years.

$\square$ From 11 to 15 years.
Big-4.

Non-Big-4.
From 5 to 10 years.
$\square$ More than 15 years.

First Section:

The following table illustrates the material weaknesses in internal control systems. First: please state whether material weaknesses in internal control systems exist or not. Second: if your answer is (yes), please state whether material weaknesses in internal control systems shall be disclosed or not.

\begin{tabular}{|c|c|c|c|c|}
\hline \multicolumn{2}{|c|}{ Existence } & \multirow{2}{*}{ Material weaknesses in Internal Control Systems } & \multicolumn{2}{|c|}{ Disclosure } \\
\hline$\overline{\text { Yes }}$ & No & & Yes & No \\
\hline \multicolumn{5}{|c|}{ 1. Inadequate controls with respect to accounting for receivables: } \\
\hline & & 1.1 Inaccurate estimation of bad debt expense. & & \\
\hline & & $\begin{array}{l}1.2 \text { Inaccurate estimation of allowance for doubtful } \\
\text { accounts. }\end{array}$ & & \\
\hline & & $\begin{array}{l}\text { 1.3 Lack of policies and procedures related to the collection } \\
\text { of account receivables. }\end{array}$ & & \\
\hline & & 1.4 Lack of confirmation of customer's accounts. & & \\
\hline \multicolumn{5}{|c|}{ 2. Inadequate controls for income tax accounting: } \\
\hline & & 2.1 Inaccurate determination of deferred income taxes. & & \\
\hline \multicolumn{2}{|c|}{ Existence } & \multirow{2}{*}{ Material Weaknesses in Internal Control Systems. } & \multicolumn{2}{|c|}{ Disclosure } \\
\hline Yes & No & & Yes & No \\
\hline & & 2.2 Improper reconciliation between the book and income tax. & & \\
\hline & & 2.3 Income tax expense is overstated. & & \\
\hline \multicolumn{5}{|c|}{$\underline{\text { 3. Inadequate controls for inventory transactions: }}$} \\
\hline & & $\begin{array}{l}3.1 \text { Inaccurate determination of value and quantity of } \\
\text { inventory. }\end{array}$ & & \\
\hline & & 3.2 Obsolete inventories are not disposed. & & \\
\hline & & $\begin{array}{l}3.3 \text { Lack of policies and procedures related to physical } \\
\text { inventory count. }\end{array}$ & & \\
\hline
\end{tabular}




\section{Insufficient controls over assets.}

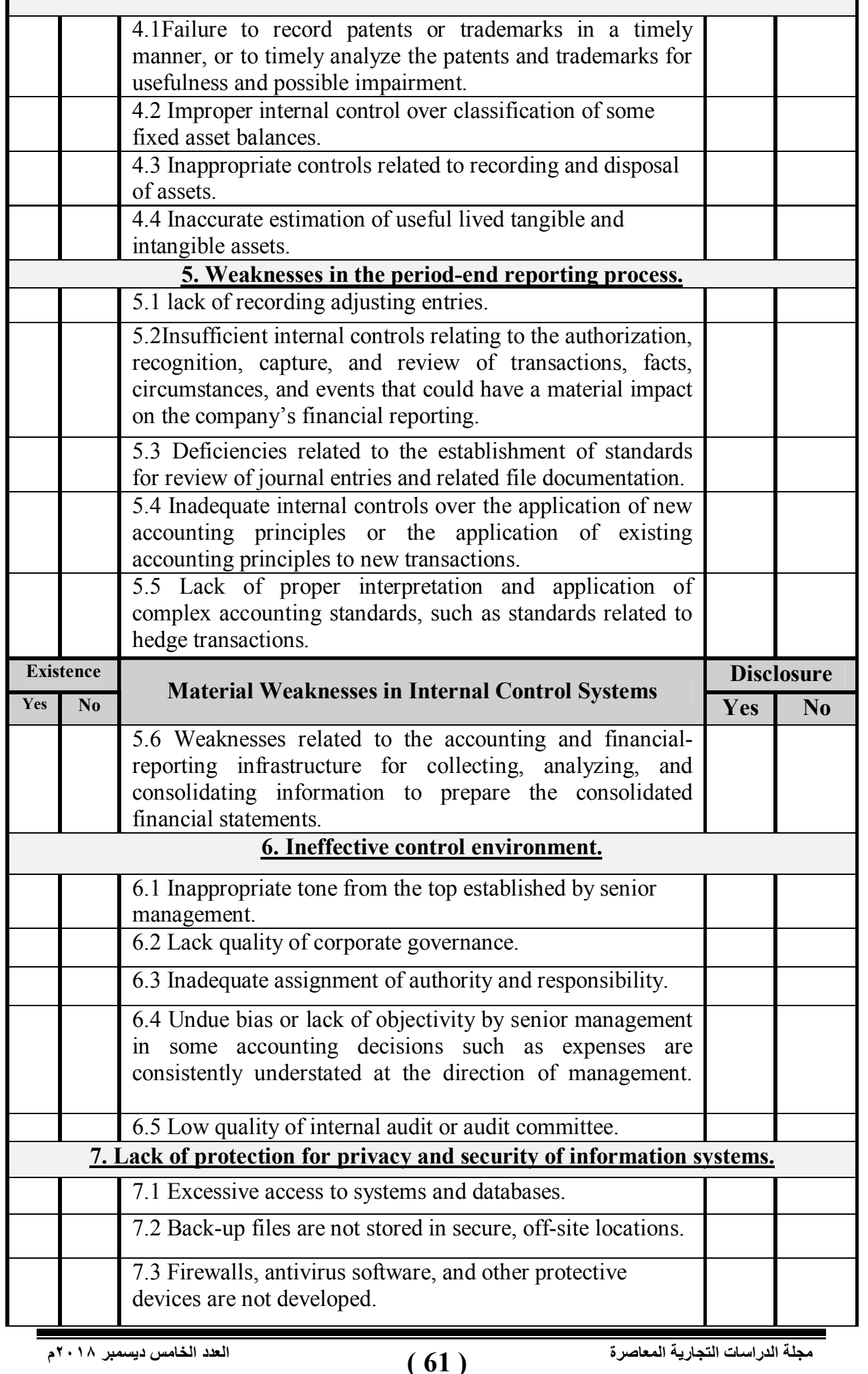




\begin{tabular}{|l|l|l|l|}
\hline \multicolumn{3}{|l|}{ 8. Insufficient controls related to revenue recognition. } \\
\hline & $\begin{array}{l}\text { 8.1 Weak internal controls related to the design and review } \\
\text { of revenue recognition policies. }\end{array}$ & & \\
\hline $\begin{array}{l}\text { 8.2 Weak internal controls related to contracting practices. } \\
\text { 8.3 Inadequate controls related to the timing of revenue } \\
\text { recognition. }\end{array}$ & & \\
\hline $\begin{array}{l}\text { 9. Improper accounting for derivatives. } \\
\text { 10. Improper accounting for accruals such as prepaid } \\
\text { expenses and accrued expenses. }\end{array}$ & $\begin{array}{l}\text { 11.Lack of qualified personnel and training in accounting, } \\
\text { finance or information systems. }\end{array}$ & & \\
\hline 12. Lack of segregation of duties. & & \\
\hline 13. Inconsistent application of accounting policies. & & \\
\hline 14. Inconsistencies in the application of company policies \\
& & & \\
\hline
\end{tabular}

\section{Second Section:}

The following statements measure characteristics of internal corporate governance mechanisms which includes (board of director and audit committee characteristics) in the Egyptian listed companies. Kindly mark $(\sqrt{ })$ for the statement that matches your opinion.

\section{A. Board of Director Characteristics:}

\section{How many members of the board of director?}

$\square$ Less than 5 members. $\square$ From 5 to 9 members. $\square$ more than 9 members.

2. How many of the board of director members are executive directors?

$\square$ Less than 5 members. $\square$ From 5 to 9 members. $\square$ more than 9 members.

3. How many of the board of director members are non-executive directors?

$\square$ Less than 5 members. $\square$ From 5 to 9 members. $\square$ more than 9 members.

4. Is CEO also the managing director of the board?

$\square$ Yes. $\quad \square$ No.

5. If your answer is (yes), what are your reasons?

*

6. How many times does the board meet with its members?

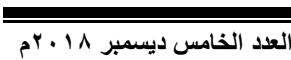


$\square 4$ times. $\square 5$ times. $\square$ More than 5 times. $\square$ Other

\section{B. Audit Committee Characteristics:}

7. How many members of the audit committee?

$\square$ Less than 3 members. $\quad \square$ More than 5 members.

$\square$ From 3 to $5 \quad \square$ Other (please specify):

members.

8. How many of the audit committee members are non-executive directors?

$\square$ Less than 3 members. $\quad \square$ More than 5 members.

$\square$ From 3 to $5 \quad \square$ Other (please specify):

members.

9. How many of the audit committee members are independent directors?

$\square$ Less than 3 members.

More than 5 members.

$\square$ From 3 to 5 members.

$\square$ Other (please specify):

10. How many of the audit committee members are financial experts?

$\square$ Less than 2 members. $\quad \square$ More than 5 members.

$\square$ From 2 to 5 members. $\quad \square$ None.

11. How many times does the audit committee meet with its members?

$\square 4$ times. $\square 5$ times. $\square$ More than 5 times. $\square$ Other

Please use this space to write any comments you wish to make.

Thank you for your time and participation.

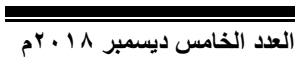

مجلة الاراسات التجارية المعاصرة 
